University of Louisville

ThinkIR: The University of Louisville's Institutional Repository

$5-2021$

\title{
The high school choral classroom as a platform for cross-cultural education: a content evaluation of the 2020 TNMEA SATB all- state repertoire.
}

Michael Ian Colavita

University of Louisville

Follow this and additional works at: https://ir.library.louisville.edu/etd

Part of the Music Education Commons

\section{Recommended Citation}

Colavita, Michael lan, "The high school choral classroom as a platform for cross-cultural education: a content evaluation of the 2020 TNMEA SATB all-state repertoire." (2021). Electronic Theses and Dissertations. Paper 3644.

https://doi.org/10.18297/etd/3644

This Master's Thesis is brought to you for free and open access by ThinkIR: The University of Louisville's Institutional Repository. It has been accepted for inclusion in Electronic Theses and Dissertations by an authorized administrator of ThinkIR: The University of Louisville's Institutional Repository. This title appears here courtesy of the author, who has retained all other copyrights. For more information, please contact thinkir@louisville.edu. 
THE HIGH SCHOOL CHORAL CLASSROOM AS A PLATFORM FOR CROSSCULTURAL EDUCATION: A CONTENT EVALUATION OF THE 2020 TNMEA SATB ALL-STATE REPERTOIRE

\author{
By \\ Michael Ian Colavita \\ B.A., B.S., Washington and Lee University, 2018 \\ M.M., University of Louisville, 2020

\begin{abstract}
A Thesis
Submitted to the Faculty of the School of Music of the University of Louisville in Partial Fulfillment of the Requirements for the Degree of
\end{abstract}

\author{
Master of Music Education \\ Department of Music Education \\ University of Louisville \\ Louisville, Kentucky
}

May 2021 
Copyright 2021 by Michael Ian Colavita

All rights reserved 

THE HIGH SCHOOL CHORAL CLASSROOM AS A PLATFORM FOR CROSSCULTURAL EDUCATION: A CONTENT EVALUATION OF THE 2020 TNMEA ALL-STATE SATB REPERTOIRE

\author{
By \\ Michael Ian Colavita \\ B.A., B.S., Washington and Lee University, 2018 \\ M.M., University of Louisville, 2020 \\ A Thesis Approved on
}

April 30, 2021

by the following Thesis Committee:

Thesis Director

Robert Amchin

Kent Hatteberg

Devin Burke 


\section{DEDICATION}

This thesis is dedicated to Noel and Barbara Piercy, who have devoted themselves toward the goal of creating a gentler and more understanding world by building a community of fellowship through music. Their tireless efforts have taught countless students to listen and be teachable. My ambition to continue doing the important work they did for me has been my inspiration in preparing this document. 


\section{ACKNOWLEDGEMENTS}

I would like to thank Dr. Robert Amchin and Dr. Kent Hatteberg, as my graduate Music Education and Choral Conducting mentors, for being patient with me and for providing me with invaluable guidance over the past three years. I would also like to thank Dr. Devin Burke for his input and assistance in preparing this document. Other mentors I would like to acknowledge include Dr. Christopher Brody, Dr. Wonjoo Ahn, and my undergraduate mentors Dr. Shane Lynch and Dr. Christopher Dobbins. Finally, I would like to acknowledge John Scozzaro, David Peterson, and Joey Vitello. These three were my first music teachers, and have been as essential in my music education journey as any other individual I could name here. Their early, unwavering encouragement was and continues to be an essential force leading me to find meaning in my life by sharing the joy of music. 


\title{
ABSTRACT \\ THE HIGH SCHOOL CHORAL CLASSROOM AS A PLATFORM FOR CROSS- CULTURAL EDUCATION: A CONTENT EVALUATION OF THE 2020 TNMEA SATB ALL-STATE REPERTOIRE
}

\author{
Michael I. Colavita
}

April 30, 2021

In the United States, there is a push toward culturally responsive music education in response to a rapidly changing student demographic. However, teaching music from unfamiliar traditions presents a unique set of challenges for the music educator. The 2020 Tennessee SATB All-State repertoire provides one example of music selected with the goal of teaching a wide array of cultural traditions. This thesis analyzes these seven pieces from a musical and pedagogical perspective to demonstrate this collection's utility for culturally responsive music education. Evaluation of the pieces demonstrated that while most of these works come from distinct cultural traditions, few present major learning challenges from a textual or tonal perspective. Multicultural works have accommodations to simplify the learning process, such as consistent use of piano accompaniment, limited text volume, and Western notational format. Conclusions from this research can inform high school teachers seeking to incorporate music from unfamiliar cultures in their classrooms. 
TABLE OF CONTENTS

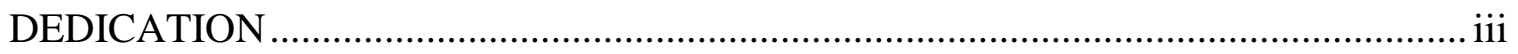

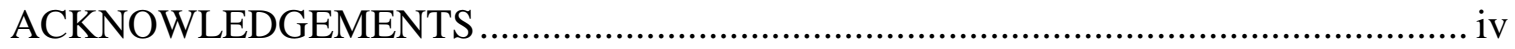

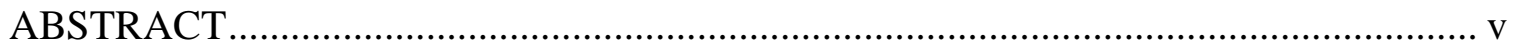

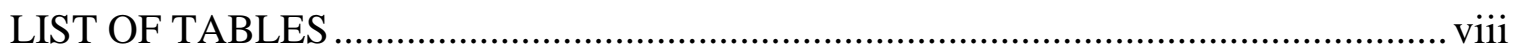

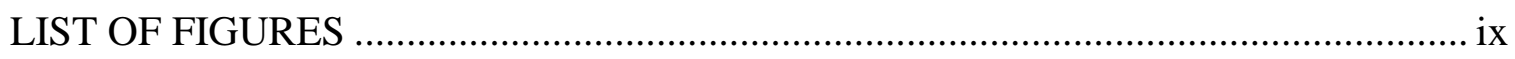

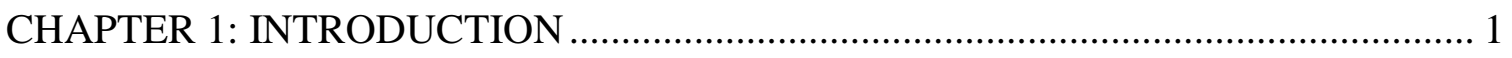

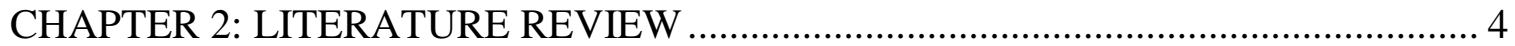

How we got here: non-Western music in the classroom ................................................ 4

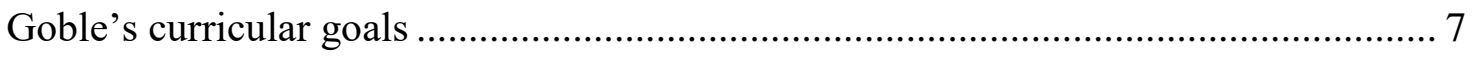

Thoughtfully Programming Varied Repertoire .......................................................... 10

Considerations for presentation of the repertoire ........................................................ 13

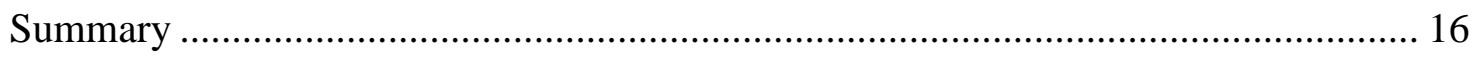

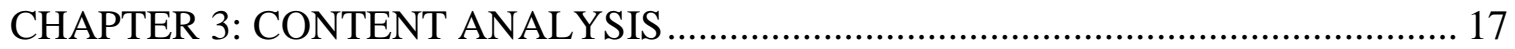

Let All the World in Every Corner Sing by Ralph Vaughan Williams ......................... 18

Arise, My Soul, Arise by Dan Forrest....................................................................... 23

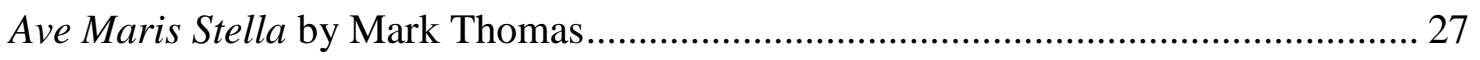

This is the Day by Keith Hampton ....................................................................... 31

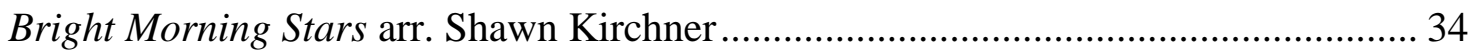

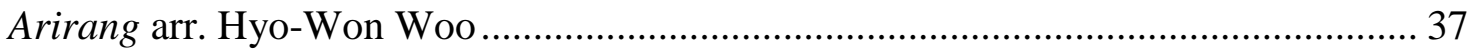

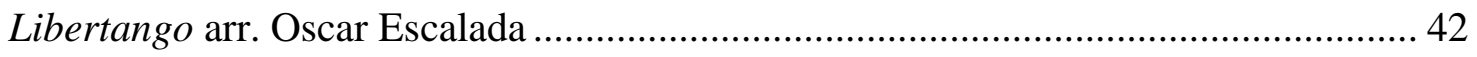

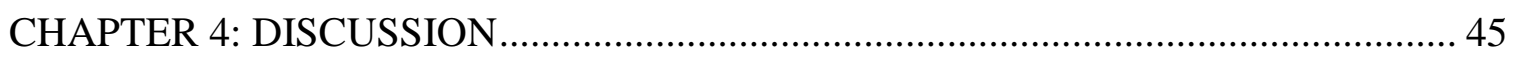

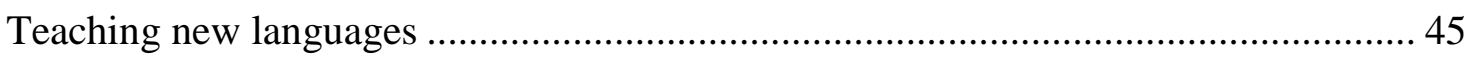

Focus on Arirang: Paying due diligence to the most unfamiliar piece ......................... 46

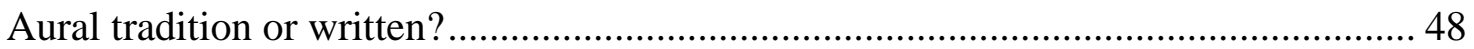

Overemphasizing the cultural tradition? ............................................................... 50

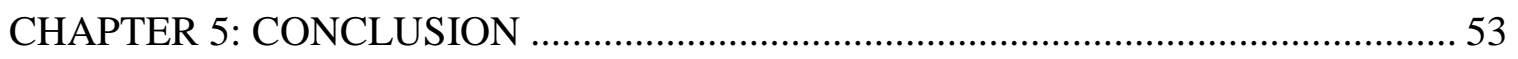

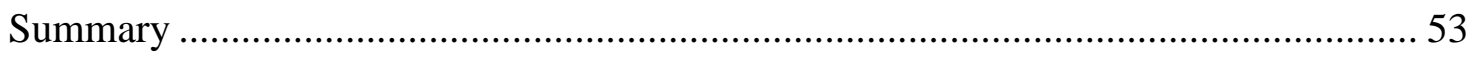




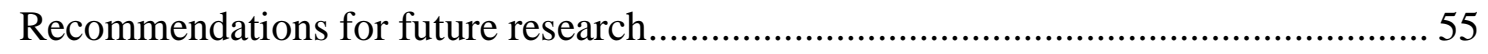

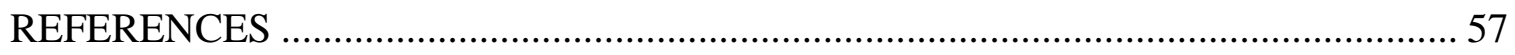

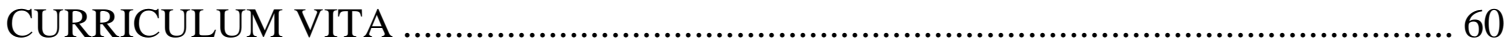




\section{LIST OF TABLES}

TABLE $\quad$ PAGE

1. Basic information for Let All the World in Every Corner Sing .................................. 18

2. Score analysis of Let All the World in Every Corner Sing ......................................... 18

3. Basic information for Arise, My Soul, Arise ……………...................................... 23

4. Score analysis of Arise, My Soul, Arise ………….................................................... 23

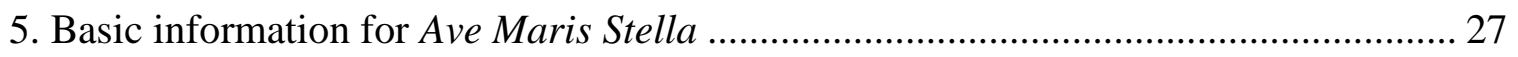

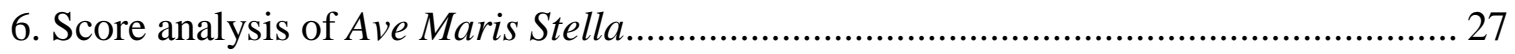

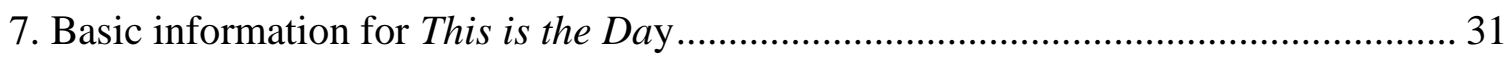

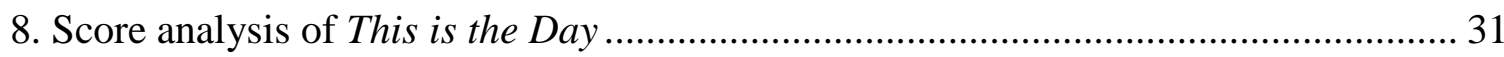

9. Basic information for Bright Morning Stars......................................................... 34

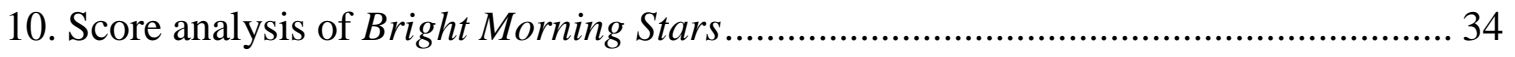

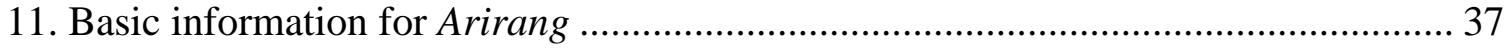

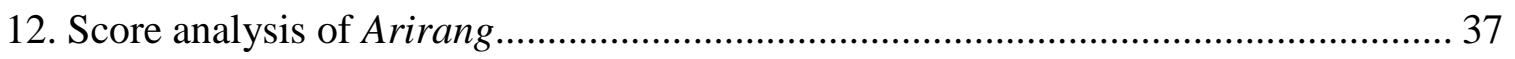

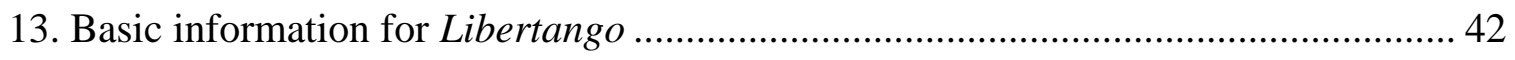

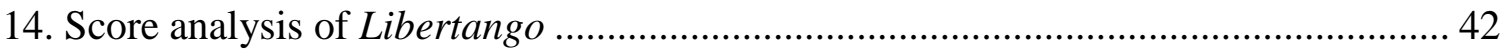




\section{LIST OF FIGURES}

\section{FIGURE}

PAGE

1. $\quad$ mm. 26-31 of Let All the World in Every Corner Sing .................................... 20

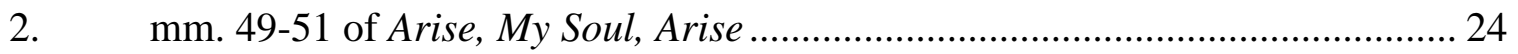

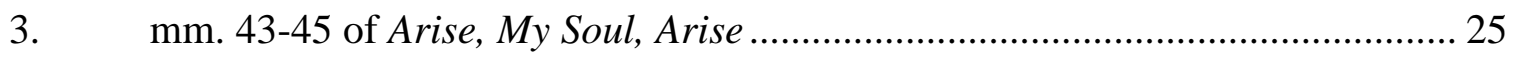

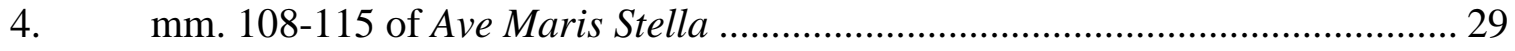

5. Note by Keith Hampton on the back page of This is the Day........................... 33

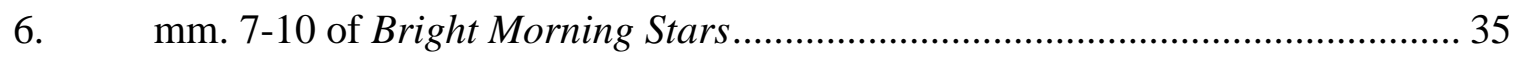

7. IPA Pronunciation Guide and Translation for Arirang .................................... 39

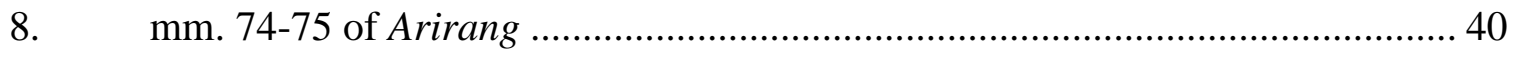

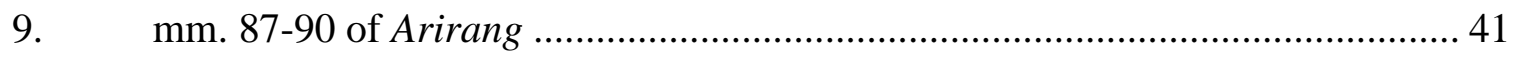

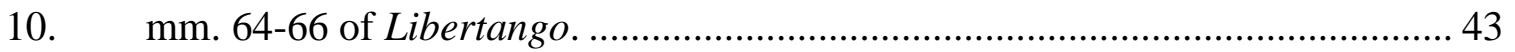

11. "Spanish pronunciation guide" for Libertango vocables. ................................. 44 


\section{CHAPTER 1: INTRODUCTION}

The world is becoming an increasingly interconnected and global society. This truth has been pushed to the forefront of peoples' minds in the midst of the COVID-19 pandemic. With in-person meetings becoming scarce during this time as a precautionary measure, technological advancements have reliably demonstrated an ability to connect people in separate places. People are more able than ever to instantaneously connect with other people from anywhere in the world with great success. It was not too long ago that a series of rivers or mountains would be considered sufficient obstacles to prevent generations of people from venturing outside a fixed radius in which they would spend the entirety of their lives. Nowadays, it is difficult to imagine anyone being isolated from the influences of the outside world, no matter where they live. In a relatively short span of time, society has not only revolutionized the technological tools at its disposal for connecting distant peoples, but also expedited the rate at which these technologies are innovated.

One inevitable byproduct of these advances is an increasing cross-exposure between world cultures. As a result, preparing students to be respectful citizens of the global community has become a foremost concern of modern-day educators. The need to integrate elements of cultural diversity and inclusion is shared by all disciplines, but there are few so well-equipped to present a globally-informed curriculum as choral music. Every society has some discernable elements of a music culture (Titon, 2018, p. 3). These 
are traditions that can be shared and appreciated around the world. The field of ethnomusicology has grown sizably in the past decades and with it, the intellectual resources necessary to present multicultural choral music in an informed and thoughtful manner. However, this wider array of resources places a greater burden of responsibility on the part of the educator. In addition to being a competent musician and teacher of musicians, it now falls upon the shoulders of the educator to be a thoughtful practitioner of world music pedagogy. Teaching from a global perspective is challenging, as it necessarily asks the educator to become familiar with that which is necessarily unfamiliar. Educators must open themselves up to new soundscapes every time they teach a piece from a new, unfamiliar culture. In presenting suggestions for teaching African-American spirituals, the prominent choral conductor André Thomas said "the culture needs to be learned first, then the music" (2019). Though student teachers can be taught about specific music cultures, eventually they may need to teach about cultures they have not previously encountered. In those instances they must become open-minded students of that culture themselves before they attempt to introduce that culture to their students.

In addition to the continuous challenges of learning, there is always the looming danger of cultural appropriation. Even the most earnest of efforts to present music from another culture can be regarded as offensive if the piece or program is improperly prepared. Unintentionally presenting tokenized renditions of aural cultural artifacts is a frightening notion for a well-intentioned choral director. As a result, there is a strong temptation to ignore the potential for cross-cultural education by firmly teaching from the traditions with which the conductor or choristers are more culturally familiar. However, 
doing so does a disservice to one's students. Students will need to engage with what is unfamiliar at some point. Whether they are equipped to do so in a way that is mindfully curious, rather than ostentatiously dismissive, is the responsibility of those charged with their education. Teaching students how to responsibly engage with the important traditions of cultures beyond their lived experience is a challenging task, and it is one of the most salient responsibilities of music educators today.

This project is intended to present pedagogical suggestions for educators seeking to emphasize the teaching of music from other cultures in their classrooms. The motivation for this work is the intensifying call for culturally responsive teaching in school systems. The following is a content analysis of the repertoire from the 2020 Tennessee SATB All-State Festival, Tennessee's most important scholastic choral event. ${ }^{1}$ This collection of seven works is drawn from a variety of music cultures all contained in the TNMEA choral list. The evaluation that follows will look at these pieces within the context of mindful cross-cultural education.

\footnotetext{
${ }^{1}$ The repertoire from the 2020 edition of the event was because the 2021 edition of the Tennessee All-State Festival did not take place as a consequence of continued restrictions due to the COVID-19 health crisis.
} 


\section{CHAPTER 2: LITERATURE REVIEW}

\section{How we got here: non-Western music in the classroom}

For centuries, immigration has been a significant force in shaping the cultural landscape of the United States. In the earliest decades of the twentieth century, "ethnic studies" were recommended for American public schools to recognize the contributions of immigrant populations. Then, "intercultural education" was implemented in the 1930s to allow immigrants to connect with their heritages in school. The terminology finally evolved into "multicultural education" shortly after the passage of the Immigration Act of 1965, which was in response to the decline in European immigrants and the increasing presence of Hispanic and Asian immigrants. This was also when U.S. Congress began producing legislation intended to accommodate for school-aged students who would learn English as a second language (Volk, 1998, p. 89). All of these changes occurred in reaction to the needs of new immigrant populations that diversified the American demographic over the course of the twentieth century. However, the rate of diversification has continued to shift the demographic makeup of the country, and the rate at which that change is occurring is also faster than previously predicted according to 2020 census data. ${ }^{2}$ In fact, though this data has yet to be finalized, it is projected that the

\footnotetext{
${ }^{2}$ To phrase in a different way, the rate of diversification in the United States is positively oriented towards increasing minority populations. Both the first and second derivatives of minority population size with respect to time have positive values. The population is increasing, and the rate at which the population is increasing is also increasing.
} 
2010 to 2020 decade will be the first recorded in the nation's history in which the white population got smaller. One other relevant consequence of this shift is that for the first time, less than half of the American population under the age of sixteen is white (Frey, 2020).

This rapid increase in the diversity of the classroom has led to the prioritization of culturally responsive teaching in choral education. However, teachers do not proportionally match the diversity of their students. While less than fifty percent of students are white, a 2017 survey by the National Center for Education found that almost eighty percent of teachers are white. Though both groups are trending toward a more diverse makeup, the student diversification rate is faster than that of the teachers (de Brey, Musu, \& McFarland, 2019, pp. 10, 28). Despite, or perhaps because of this discrepancy, the choral community has demonstrated an adamant commitment to the tenets of culturally responsive teaching, and that is evidenced by the recent activities of the American Choral Director's Association (ACDA). For the first time in many years, ACDA amended its Constitution and Bylaws in 2021 to include two new purpose statements in addition to the existing twelve. They are "to foster and promote choral singing in the pursuit of peace and justice that enhances social and emotional well-being" and "to foster and promote diversity and inclusivity through active engagement with underrepresented choral musicians and potential choral participants" (2021). This year's ACDA National Conference is centered on the ideas of diversity, equity, and inclusion, and is subtitled "Celebrating Diversity in Music" (Bumgarner, 2021). The November and December issues of ACDA's publication, the Choral Journal, were entitled Sounds of Blackness: A Focus Issue on Racial Harmony and Just In Case You've Forgotten: A 
Focus Issue on Black Composition and Arranging (Boyd, 2020). The inclusion of music from around the world has long been a tenet embraced by many U.S. music educators; however it has only recently become such a central curricular concern (Goble, 2010, p. 234). Given the demographic mismatch between teachers and students, most teachers will need to program at least some music from which they feel culturally distant in order to even parallel the cultural diversity of the classroom. The clear direction of society's diversification necessitates the embrace of world music pedagogy as a curricular focal point and natural outgrowth of culturally responsive education.

The perspectives that ethnomusicology has given rise to indicate there are, at present, more different kinds of music available to more different kinds of people than ever before in history (Hodges \& Sebald, 2011, p. 323). In considering how rapidly music can be transmitted, it is worth noting that music cultures are not fixed entities. Music cultures are dynamic and continuously adapt in response to inside and outside pressures. As the notable musicologist Jeff Todd Titon states, "It is wrong to think of a musicculture as something isolated... the people in a music-culture need not share the same language, nationality, or ethnic origin" (2018, pp. 28-29). American society is largely characterized by its diversity, but it is also characterized by the overwhelming presence of music in many facets of American life. It would be tremendously difficult to live in America without interacting with music regularly, and not just a single type of music. Music tends to provide a reflection of its host society, as the sociologist Christopher Ballantine states: "social structures crystallize in musical structures; that in various ways and with varying degrees of critical awareness, the musical microcosm replicates the social macrocosm" $(1984$, p. 5). Though this is a broad claim, it stands to reason that the 
music American citizens interact with every day at home, school, work, and elsewhere is reflective of the vastly diverse nature of American society at large.

\section{Goble's curricular goals}

In his book What's So Important about Music Education?, J. Scott Goble articulates the necessity of prioritizing cultural engagement in the music classroom. The book comprehensively attends to a variety of functions that American public school music education could serve, and he ultimately claims that this particular function is one of singular importance. Goble summarizes his work by making recommendations for three curricular goals music educators should prioritize (Goble, 2010, p. 264).

The first goal is to introduce students to "the full musical dimension of human life." In elaborating on this goal, Goble explains the utility of experiencing the "full musical dimension of human life" is the psychosocial equilibration of the self. Psychosocial equilibrium is the attainment of a state of both psychological and social equilibrium. Not all musical practices and cultures work to affect this psychosocial equilibration in the same way. Students should be empowered by their teachers to engage meaningfully with a variety of music traditions such that they may move towards this equilibrium state (p. 267). The second goal is to see how musical practices influence and appear in a student's own culture. Acquisition of a more global perspective should not come at the cost of engaging with one's own community. Music is widely present in the U.S. as a source of community engagement, with over 100,000 active nonprofit arts organizations nationwide (Hodges \& Sebald, 2011, p. 307). The wide presence of these groups combined with the wide presence of popular media means there are countless 
ways in which people in the U.S. interact with a variety of music. Music teachers have a role in producing conscientious citizens who are capable of understanding the way music shapes the sociopolitical climate where they live, as the medium certainly possesses great power to do so in the United States. One challenge of this goal is accomplishing it for a racially and ethnically diverse student body. Whether the public school system should be tasked with the transmittance of cultural values becomes a more difficult question when the cultural distribution of the school is itself in rapid flux (Froehlich, 2007, p. 92).

The third goal is empowering students with the skills necessary to engage in the musical practices of other cultures. This goal is only achievable through the thoughtful incorporation of foreign music practices in one's own classroom. The adoption of a multicultural perspective on music teaching has been encouraged since the mid-twentieth century, but it has been considered an absolute necessity as early as the May 1983 edition of the Music Educators Journal, when the publication first asserted that music educators "must" reform their curriculum as such (Dodds, 1983, pp. 33-34). This assertion was foreshadowed by the Tanglewood Declaration, prepared in 1967 as a byproduct of the Tanglewood Symposium. Its second point reads "Music of all periods, styles, forms, and cultures belongs in the curriculum. The musical repertory should be expanded to involve music of our time in its rich variety, including currently popular teenage music and avantgarde music, American folk music, and the music of other cultures" (Hoffer, 2008, p. 73). Expanding the teachable repertoire to include popular music and music from other cultures presented a significant change for the routines of many twentieth-century educators. Different teachers had different perspectives regarding how they might best implement this change. Bennett Reimer considers multicultural music education to 
propose a dilemma, which he resolves by postulating we can find cultural music we are more comfortable with, rather than striving to go as far from the West as possible (2003, p. 194). Patricia Shehan Campbell claims that studying music of fewer traditions in depth is of greater benefit than briefly touching on many traditions in school music programs (2002, p. 31). Such groups as the Music of Non-Western Cultures committee have been formed expressly for the purpose of finding the optimal solution for this priority. In their own words, they were formed "to suggest procedures and prepare materials for use in presenting different musical systems of the world as integral parts of the music education curricula in American elementary and secondary schools, colleges, and universities" (1969). It is also worth noting that multicultural engagement through travel has become more available than ever before. The increasing accessibility and relatively inexpensive nature of air travel and the proliferation of choral festivals and competitions have opened up many avenues for choral programs around the world to explore touring options. Though it has long been a tradition of American collegiate choral ensembles and glee clubs to travel abroad, there is more travel access for groups in other nations as well. In particular, Asian choirs are travelling internationally far more than they ever have, and being privy to the activities of these groups is one way choral directors can provide crosscultural engagement for their students (Quadros, 2019, p. 145). That being said, culture bearers need not necessarily always come from distant nations. One may also seek them out in one's own school or community. Involving a diverse body of voices is an important step in educating students to appreciate and positively experience unfamiliar cultures. This step is all the more significant to the group if these voices are already a part of one of their communities. 
All of Goble's curricular goals can be viewed as components of an education aimed at teaching students to be culturally responsible. Goble is not alone in determining this to be important. The National Association for Music Education has affirmed this idea in its own statement of educational standards, stating, "Students need to respond to music, as well as to their culture, their community, and their colleagues" (2014 Music Standards, 2014). Undoubtedly, this task is a significant priority nowadays. The challenge begins once one determines how the ambition to meet this standard might manifest itself as curricular decisions.

\section{Thoughtfully Programming Varied Repertoire}

One of the most important decisions a teacher makes toward the fulfillment of a culturally responsive music curriculum is what multicultural repertoire to study in a given academic year. In the case of the TNMEA All-State repertoire, the selections were made by the guest clinician, Dr. Pearl Shangkuan. Two of the seven works are a part of her own choral series with the publisher earthsongs, and she stated the following regarding her selection of Ave Maris Stella and This is the Day, "In general, when I use a piece(s) from my own series, it's to enhance the learning experience for the students with my sharing of insights from up-close personal experience of working with the composers" (Personal

communication, 2021). If a conductor is able to program works by living composers with whom they can collaborate, this effort can provide a much more meaningful experience for the students. Dr. Shangkuan said the other works also needed to "fit within the larger context and considerations of the program itself" (2021). Selecting repertoire involves considering the individual value of each piece while also considering the larger 
perspective of the program as a whole. Presenting a program that is well-balanced, achievable, and with a good sense of thematic flow necessitates making every selection with due consideration of the others.

Where possible, it may serve the music teacher well to not select repertoire all alone. It might be in the best interest of teachers to solicit feedback from students, parents, and the local community about what sort of music they would like to hear at performances, and what sort of music they believe would be appropriate (Froehlich, 2007, p. 43). It is important to be receptive to the voices of community members amidst a constantly changing sociopolitical environment (Dungee, 2020, p. 12). The repertoire selections made by a teacher send a message to the community about their values. As Hildegard Froehlich states, "musical selections, rehearsed and performed in concert, symbolize in the eyes and ears of the student performers and the school community alike what the teacher stands for musically and culturally" (2007, p. 43). Though several of the state lists from the past few years include a multitude of musical traditions in their repertoire, there are many lists that do not include any music from outside the Western canon or from outside the English language (J.W. Pepper, 2021).

Being aware of popular opinion is a necessary asset in programming music that will ultimately be productive toward the goal of providing a positive experience for the students. Moreover, being flexible in this way can allow for poignant experiences for students wanting to share their own music cultures. Composer Ethan Sperry, in reflecting on an unpublished arrangement of his, stated that the piece came about because a music teacher commissioned him to work with two new students who were of Tongan descent and who wanted to sing and teach Tongan folk music to the class (Ešenvalds, 2021). 
Encouraging these sorts of opportunities by empowering student culture bearers to share their heritage can be one of the most powerful ways choral conductors act as intercommunity bridge builders (Froehlich, p. 43). It is useful to consider which music cultures a teacher would present in a given academic year, in accordance with the diversity of students at hand as well as that of the community at large. However, opportunities may present themselves throughout the course of the year, at which point it is the job of the educator to listen first and allow room for flexibility in programming. It is with the humility necessary to listen to the opinions of others that a teacher might best avoid the inevitable dangers of cultural appropriation in making these important repertoire selections (Cho, 2015, p. 60).

Most teachers will not have the resources of time or knowledge to assemble scores of multicultural music from scratch. This is especially true when instructors lack familiarity with the music they want to program. There is, as a response to the increased desire to program multicultural music, an excess of commercially available scores that choral teachers can use as a resource for teaching such music (Bartolome, 2019, p. 89). In fact, many of the available scores of this sort of music have been adapted to accommodate the needs of a Western ensemble. When done thoughtfully, adaptations that make the music more accessible can be a valid and helpful approach to infusing a more global orientation into the choral curriculum. However, not all publishers will approach the issue of cultural sensitivity and authenticity with the same seriousness (p. 90). In selecting multicultural repertoire, understanding the philosophy of the publisher and of the arranger is a useful litmus test for determining the appropriateness of commercially available arrangements. The ethnomusicologist Carlos Abril goes so far as 
to state such an examination is the single most important consideration an educator should have in the selection process, "the systematic examination of cultural validity, bias, and practicality will ensure the integrity of the selections" (2006, p. 45).

\section{Considerations for presentation of the repertoire}

It is useful to provide information to an audience receiving a music performance in order to provide a fuller picture of the purpose and importance of the work. Contextualizing pieces from some cultures for an audience might be better done by way of speaking directly to them as a preface to performance rather than through a written program note (Bartolome, 2019, p. 102). Such information might be structured as a timely reaction to recent events to which the audience's attention should be drawn. For instance, works of a threatened group might be performed as an act of solidarity. In such instances, speaking with the audience could provide a more meaningful justification for the selection of the pieces than a pre-written note.

The performing activities of the students should grow out of listening examples. Such listening examples should include original source material, such as field recordings, as well as contemporary interpretations of traditional songs. In this way, students gain a knowledge of how the music would have sounded in its authentic form as well as what sort of culturally valid performance they could strive to deliver now. The terminological distinction between "authentic" and "culturally valid" is important, and is a relatively recent development in the research literature (Bowers, 2021). It is impossible for choristers to perform works from outside their own cultural heritage in a truly "authentic" way, and such should not be their ultimate goal. Acknowledging that truth is necessary, 
and requires a degree of what Hook refers to as "cultural humility" (Hook, Davis, Owen, Worthington, \& Utsey, 2013, p. 353). However, by understanding the culture in a meaningful way, choirs can still perform music from other cultures in a way that honors them and, as Abril says, is "culturally valid" (2006, p. 40).

In addition to understanding the basic nature and flow of the music, listening examples confer the practical benefit of teaching the diction of unfamiliar languages. Having standard-issue pronunciation guides such as IPA (International Phonetic Alphabet) and Romanized translations are of tremendous value, but even such useful guides as these have shortcomings in the case of certain languages. Depending on the unfamiliarity of the language, thinking about words in terms of something heard rather than something read can be of great utility (Bartolome, p. 91). Different traditions also represent different sound ideals. The question to ask when preparing this sort of music is not only how to achieve the necessary changes to the ensemble sound to embody different sound ideals, but also how to do so in a vocally safe and culturally thoughtful manner (p. 97). It is insufficient to teach music from all cultures in the mold of a single sound ideal. As Sperry and Goetze state of performing vocal music from other cultures, "Approximating vocal timbre is an important gesture because it honors their way of singing as well as the people and the culture from which the song comes" (2014, p. 65).

It is also important for the teacher to emphasize the elements of unfamiliar music traditions that deviate from the expectations instilled by a Western musical heritage. One such important deviation is the role of the conductor. When performing music from different cultures, the role of the conductor could be maintained, adjusted, or dispensed with altogether based on the performance practice expectations of their culture's music 
leaders. In some traditions, the conductor role might be filled by a drummer who leads the song. In others, the role of a leader is omitted entirely. Especially for younger singers, having the sense of direction that comes from a music teacher conducting the group is beneficial, though conductors might benefit from experimenting with varying their role when performing music from cultures that would see such a shift as appropriate (Bartolome, p. 99). In the same vein, it is necessary for conductors to understand the ways traditional score study provides an incomplete solution for understanding multicultural music. In preparing to teach multicultural works, the aspects of the work that dwell outside traditional preparation protocols should be identified and given due diligence.

Using multiple notational systems in the classroom is another pedagogical strategy that could be effectively employed. Though the world of music consists of many valid systems, teachers often only utilize a single one. Teaching music that has arisen from non-Western systems through the lens of Western notation will present certain limitations and challenges. Extensively using other systems may be unproductive, but doing so occasionally and thoughtfully can be useful (Glass, 2021, p. 31). Alternatively, there are many music cultures that have an aural tradition of music learning, and incorporating music that can be learned without notated scores is another way of dispensing with the notion that all music can or should be representable in a single system of signs (Titon, 2018, p. 26). A balance must be struck between presenting the music in a learnable way while still maintaining the integrity of the source material. 


\section{Summary}

In order to be culturally responsive teachers, it is necessary to become comfortable with the process of teaching music from unfamiliar cultures. The process of learning about another culture's music, though always a challenge, is also very exciting. It is humbling to accept that music teachers striving to present their students with music from a wide array of traditions will first need to embrace being lifelong students themselves. Though the process is challenging, the practice of incorporating music from outside the Western canon will reap great benefits for any program. By doing this, we dissolve the notion of school music being separate from personal music, we present music that more students will relate to and ultimately join choir to participate in, and we teach students that if they are willing to listen to what is at first unfamiliar, they may

discover musical worlds that stoke a lifelong love for singing harmoniously with others. 


\section{CHAPTER 3: CONTENT ANALYSIS}

What follows is a formal music analysis of each of the seven works included in the 2020 SATB Tennessee All-State repertoire. Basic information, such as title, composer, year of publication, tonality, duration, and range of voices will be presented in a table for each piece. After that will be another table, which will provide an analysis of the form and structure of the music. This second table will break down each piece into its major sections, with smaller phrase groupings parenthetically noted. Corresponding tempo, meter, textual, and tonal changes will be noted section-by-section. Each major section will also be accompanied by a short description, highlighting certain important details for a conductor to consider. Most commonly, this description will note entrances by different sections, and will use the following shorthand: S for "Soprano," A for “Alto," T for "Tenor," and B for "Bass." Individual sections as well as combinations of sections will be referred to using this single-letter shorthand. Following these tables will be other elements for analysis such as edition formatting, pedagogical challenges, and particularly teachable moments in the music. 


\section{Let All the World in Every Corner Sing by Ralph Vaughan Williams}

Table 1: Basic information for Let All the World in Every Corner Sing

\begin{tabular}{|l|l|}
\hline Title & $\begin{array}{l}\text { Let All the World in Every Corner Sing (Antiphon from Five } \\
\text { Mystical Songs) }\end{array}$ \\
\hline Composer & Ralph Vaughan Williams, ed. Craig Courtney \\
\hline Publisher & Beckenhorst Press, Inc. \\
\hline Year & 1911 (ed. 2010) \\
\hline Accompaniment & Piano four-hands \\
\hline Tonality & D Major \\
\hline Range & $\begin{array}{l}\text { Soprano: F\#4-G5 } \\
\text { Alto: D4-D5 } \\
\text { Tenor: F3-A4 } \\
\text { Bass: G2-D4 }\end{array}$ \\
\hline Duration & 3:30 \\
\hline
\end{tabular}

Table 2: Score analysis of Let All the World in Every Corner Sing

\begin{tabular}{|l|l|l|l|l|}
\hline $\begin{array}{l}\text { Sections, } \\
\text { (Phrase } \\
\text { Groupings })\end{array}$ & $\begin{array}{l}\text { Tempo, } \\
{[\text { Meter }]}\end{array}$ & Tonality & Text & Description, Notes \\
\hline $\begin{array}{l}\text { mm. 1-14 } \\
(3+4+4+3)\end{array}$ & $\begin{array}{l}\text { Allegro } \\
(\text { J=ca.132-144) } \\
{[\mathbf{3 / 4}]}\end{array}$ & D Major & & $\begin{array}{l}\text { Piano } \\
\text { accompaniment } \\
\text { introduction }\end{array}$ \\
\hline $\begin{array}{l}\text { mm. 15-34 } \\
(5+6+2+3+4)\end{array}$ & & $\begin{array}{l}\text { Let all the world } \\
\text { in every corner } \\
\text { sing, } \\
\text { My God and } \\
\text { King. }\end{array}$ & $\begin{array}{l}\text { TB melodic } \\
\text { introduction, then } \\
\text { restatement of } \\
\text { melody by } \\
\text { homophonic SATB }\end{array}$ \\
\hline $\begin{array}{l}\text { mm. 35-49 } \\
(6+3+6)\end{array}$ & & $\begin{array}{l}\text { Eb Major } \\
\text { (m.42-48) }\end{array}$ & $\begin{array}{l}\text { The heav'ns are } \\
\text { not too high, } \\
\text { His praise may } \\
\text { thither fly: } \\
\text { The earth is not } \\
\text { too low, }\end{array}$ & $\begin{array}{l}\text { ST in octaves, then } \\
\text { AB in octaves }\end{array}$ \\
\hline $\begin{array}{l}\text { His praises there } \\
\text { may grow. }\end{array}$ & \\
$(5+5+4+3)$ & & $\begin{array}{l}\text { F Minor } \\
\text { (m. 49- } \\
\text { 52), D } \\
\text { Major by } \\
\text { m.57 via } \\
\text { Bb Major } \\
\text { chord }\end{array}$ & $\begin{array}{l}\text { Let all the world } \\
\text { in every corner } \\
\text { sing, }\end{array}$ & $\begin{array}{l}\text { Layered entrances of } \\
\text { parts (T then AB then } \\
\text { S), then interlude }\end{array}$ \\
& & & \\
\hline
\end{tabular}




\begin{tabular}{|c|c|c|c|c|}
\hline $\begin{array}{l}\mathrm{mm} \cdot 67-80 \\
(6+4+4)\end{array}$ & & & $\begin{array}{l}\text { Let all the world } \\
\text { in every corner } \\
\text { sing, My God } \\
\text { and King. }\end{array}$ & $\begin{array}{l}\text { Similar homophonic } \\
\text { section as at m. } 20 \text {, } \\
\text { then interlude }\end{array}$ \\
\hline $\begin{array}{l}\mathrm{mm} .81-89 \\
(2+3+2+2)\end{array}$ & & B Major & $\begin{array}{l}\text { The Church with } \\
\text { Psalms must } \\
\text { shout, } \\
\text { No door can } \\
\text { keep them out: }\end{array}$ & $\begin{array}{l}\text { SA statement in 2- } \\
\text { part harmony }\end{array}$ \\
\hline $\begin{array}{l}\mathrm{mm} \cdot 90-96 \\
(3+4)\end{array}$ & [4/4] (m.93-94) & Db Major & $\begin{array}{l}\text { But above all, } \\
\text { the heart } \\
\text { Must bear the } \\
\text { longest part. }\end{array}$ & $\begin{array}{l}\text { SATB homophonic } \\
\text { statement }\end{array}$ \\
\hline $\begin{array}{l}\mathrm{mm} .97-111 \\
(2+2+2+4+3 \\
+2)\end{array}$ & $\begin{array}{l}\text { Largamente } \\
(\mathrm{m} .110)\end{array}$ & $\begin{array}{l}\text { C Major } \\
\text { (m.97- } \\
104), G \\
\text { Major } \\
\text { (m.105- } \\
\text { 109), D } \\
\text { Major } \\
\text { (m.110) }\end{array}$ & $\begin{array}{l}\text { Let all the world } \\
\text { in every corner } \\
\text { sing, } \\
\text { My God and } \\
\text { King. }\end{array}$ & $\begin{array}{l}\text { Layered entrance on } \\
\text { "Let All the World" } \\
\text { motif, B then A then } \\
\text { S then T }\end{array}$ \\
\hline $\begin{array}{l}\mathrm{mm} .112-123 \\
(3+2+3+4)\end{array}$ & $\begin{array}{l}\text { Tempo I, } \\
\text { Poco Più } \\
\text { Lento (m. 120) } \\
\text { [4/4] (m.121- } \\
\text { 123) }\end{array}$ & & $\begin{array}{l}\text { Let all the world } \\
\text { in every corner } \\
\text { sing, } \\
\text { My God and } \\
\text { King. }\end{array}$ & $\begin{array}{l}\text { Short call and } \\
\text { response between } \\
\text { choir and rapid } \\
\text { accompaniment. }\end{array}$ \\
\hline $\begin{array}{l}\mathrm{mm} .124-137 \\
(4+4+4+2)\end{array}$ & $\begin{array}{l}\text { Tempo I } \\
{[3 / 4]}\end{array}$ & & & $\begin{array}{l}\text { Accompaniment } \\
\text { outro }\end{array}$ \\
\hline
\end{tabular}

\section{Further Musical Analysis/Considerations}

Of all the works included in this collection, Let All the World in Every Corner

Sing is the only one by a classical "master composer" of the Western art music canon.

The resources available to the conductor preparing a work by as noteworthy a composer as Ralph Vaughan Williams are plentiful. However, because of the availability of broader common knowledge of the piece, there may be a greater burden of expectation for its performance. Moreover, the music of Ralph Vaughan Williams is intricate, especially for students at the primary school level. There are more tonal shifts in this work than there are in the others of this collection, many of them to harmonically distant keys. Unlike the 
other works, there is a more dynamic sense of shifting between major and minor tonalities. There are also a greater number of accidentals present than there are in the other pieces. Using a system of tonal anchoring like moveable Do solfège would be more difficult in this piece because the great number of accidentals would result in more modified syllables and a greater incidence of reassigning Do to accommodate tonal shifts.

The work also presents unique challenges rhythmically. A strong sense of downbeat is not always present, often being obscured by instances of hemiola both in the accompaniment and in the vocal parts. One notable instance of this here is in the repeated figure on "My God and King," which first occurs in mm. 26-30 as seen in Figure 1.

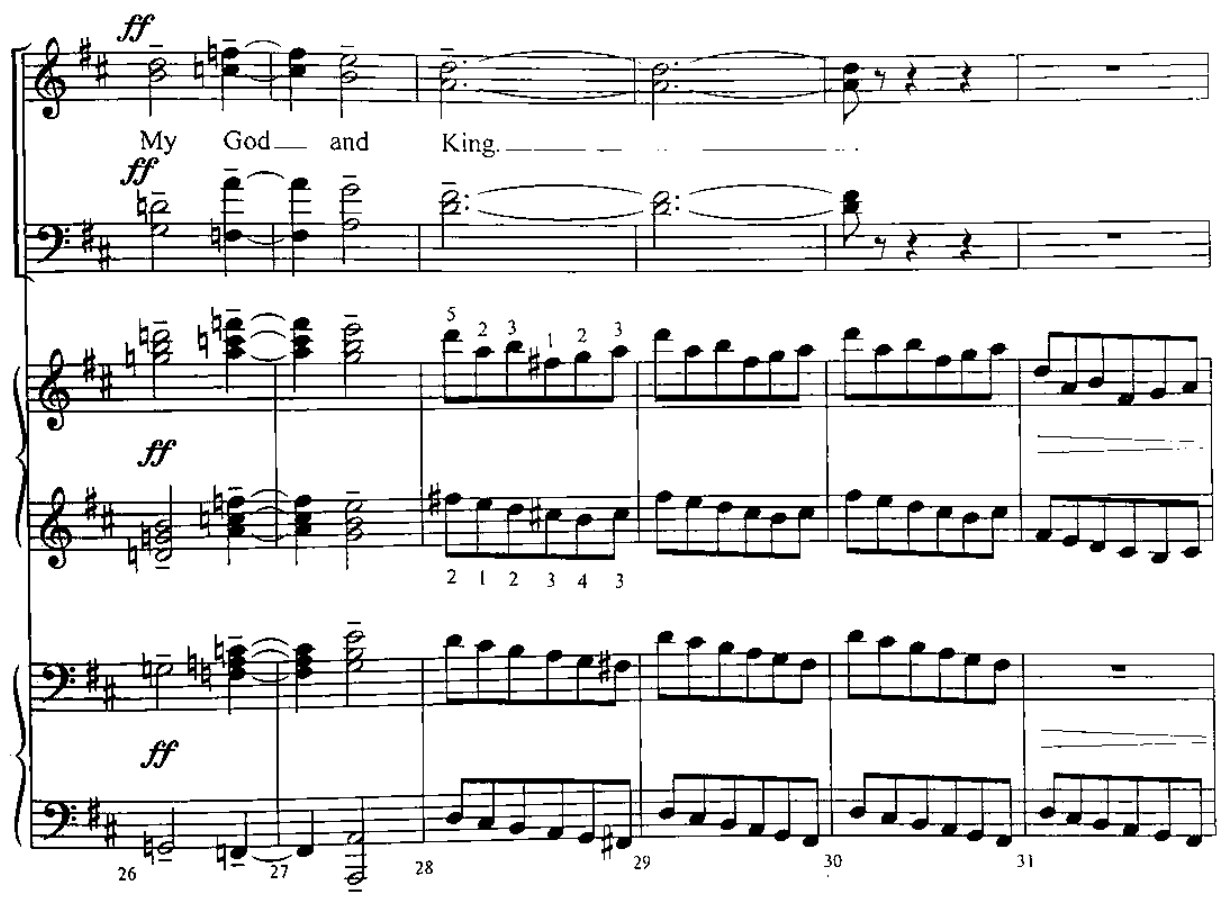

Figure 1: mm. 26-31 of Let All the World in Every Corner Sing

Finally, the work presents difficulties in terms of vocal range. Though the general ranges are similar to other works in this collection of repertoire, the tessituras of the individual voice parts are considerably wider than the other works. As an example of this, the tenor 
voice sings an A4 at the climax of each iteration of the aforementioned "My God and King" phrase.

Something else to be considered when preparing a movement from a major work is whether the arrangement faithfully captures the essence of the original music. If a work was originally scored for a chorus with a full symphonic orchestra, a piano reduction, however well-prepared, inevitably omits some aspects of the accompaniment. Fortunately, in the case of this work, Ralph Vaughan Williams himself arranged Five Mystical Songs for several different orchestrations, and as such demonstrated that he intended the work to be flexible with its accompaniment. In fact, the entire Five Mystical Songs could be sung individually by a baritone soloist, the choir being scored as optional. This truth is evident in the moments of this arrangement where TB sing in unison, which would originally have been passages for the baritone soloist. Interestingly, among Ralph Vaughan Williams's arrangements of Five Mystical Songs are a version with just piano, a version with piano and string quartet, a wind band version, and a full orchestral version. The score's note from the arranger states, "The impulse to create this four-hand accompaniment was a result of performing the two-hand version and leaving the stage unsatisfied with my attempt to render the printed page" (Williams, 2010, p. 2). The editor affirms this note from the arranger stating, "Craig Courtney's four-hand piano setting lends a much fuller and brilliant accompaniment to the overall exciting impact of this beautiful piece" (Williams, p. 2). Given that a standard piano accompaniment version exists that was prepared by Ralph Vaughan Williams himself, it would be worthwhile for a conductor seeking to prepare this piece to compare this work with the original reduction 
by the composer and come to an individual determination whether the rearrangement is justified or not. 
Arise, My Soul, Arise by Dan Forrest

Table 3: Basic information for Arise, My Soul, Arise

\begin{tabular}{|l|l|}
\hline Title & Arise, My Soul, Arise \\
\hline Composer & Dan Forrest (Chodan) \\
\hline Publisher & Beckenhorst Press, Inc. \\
\hline Year & 2012 \\
\hline Accompaniment & Piano, optional Violin \\
\hline Tonality & D Major (mm. 1-37), Eb Major (mm. 38-59) \\
\hline Range & Soprano: A3-G5 \\
& Alto: A3-F5 \\
& Tenor: A2-F4 \\
& Bass: G2-D4 \\
\hline Duration & 4:00 \\
\hline
\end{tabular}

Table 4: Score analysis of Arise, My Soul, Arise

\begin{tabular}{|c|c|c|c|c|}
\hline $\begin{array}{l}\text { Sections, } \\
\text { (Phrase } \\
\text { Groupings) }\end{array}$ & $\begin{array}{l}\text { Tempo, } \\
\text { [Meter] }\end{array}$ & Tonality & Text & $\begin{array}{l}\text { Description, } \\
\text { Notes }\end{array}$ \\
\hline $\begin{array}{l}\text { mm. } 1-5 \\
(2+2+1)\end{array}$ & $\begin{array}{l}\text { Slowly, rubato } \\
(d=c a .60) \\
{[4 / 4]}\end{array}$ & D Major & - & $\begin{array}{l}\text { Instrumental } \\
\text { introduction }\end{array}$ \\
\hline $\begin{array}{l}\text { mm. 6-18 } \\
(4+3+3+3)\end{array}$ & $\begin{array}{l}\text { Slower, } \\
\text { rubato } \\
(d=c a .56) \\
{[3 / 4](m .14)} \\
{[4 / 4](m .15-)}\end{array}$ & & $\begin{array}{l}\text { Arise my soul, arise, } \\
\text { Shake off thy guilty } \\
\text { fears: } \\
\text { The bleeding } \\
\text { Sacrifice in my } \\
\text { behalf appears: } \\
\text { Before the Throne, } \\
\text { my Surety stands. } \\
\text { My name is written } \\
\text { on His hands. }\end{array}$ & $\begin{array}{l}\text { Octave melody in } \\
\text { SATB, } \\
\text { momentary split } \\
\text { into 4-part } \\
\text { homophony, final } \\
\text { phrase trades off } \\
\text { from unison SA } \\
\text { to unison TB }\end{array}$ \\
\hline $\begin{array}{l}\text { mm. 19-37 } \\
(4+5+3+3+4)\end{array}$ & $\begin{array}{l}\text { Più mosso } \\
(\mathrm{d}=\mathrm{ca} .63) \\
{[2 / 4](\mathrm{m} .26)} \\
{[4 / 4](\mathrm{m} .27-28)} \\
{[3 / 4](\mathrm{m} .29)} \\
{[4 / 4](\mathrm{m} .30-)}\end{array}$ & & $\begin{array}{l}\text { Five bleeding wounds } \\
\text { He bears, received on } \\
\text { Calvary, } \\
\text { They pour effectual } \\
\text { prayers, they strongly } \\
\text { plead for me: } \\
\text { "Forgive him, O, } \\
\text { forgive," they cry, } \\
\text { "nor let that } \\
\text { ransomed sinner die." }\end{array}$ & $\begin{array}{l}\text { Brief instrumental } \\
\text { interlude } \\
\text { followed by } \\
\text { continuation of } \\
\text { SA unison trading } \\
\text { off with TB } \\
\text { unison. } \\
\text { Occasional two- } \\
\text { part splitting, end } \\
\text { on unison D4 } \\
\end{array}$ \\
\hline
\end{tabular}




\begin{tabular}{|c|c|c|c|c|}
\hline $\begin{array}{l}\text { mm. 38-52 } \\
(6+3+3+3)\end{array}$ & $\begin{array}{l}\text { Broadly } \\
(\mathrm{d}=\text { ca.60) } \\
{[2 / 4](\mathrm{m} .41)} \\
{[4 / 4](\mathrm{m} .42)} \\
{[2 / 4](\mathrm{m} .43)} \\
\text { Slightly } \\
\text { slower, } \\
\text { deliberately } \\
{[4 / 4](\mathrm{m} .44)} \\
{[3 / 4](\mathrm{m} .45)} \\
{[4 / 4](\mathrm{m} .46-51)} \\
{[2 / 4](\mathrm{m} .52)}\end{array}$ & Eb Major & $\begin{array}{l}\text { My God is } \\
\text { reconciled, His voice } \\
\text { I hear, He owns His } \\
\text { child, I can no longer } \\
\text { fear; } \\
\text { With confidence I } \\
\text { now draw nigh, } \\
\text { And "Abba, Father," } \\
\text { cry. } \\
\text { Arise, my soul, arise! }\end{array}$ & $\begin{array}{l}\text { Three-part } \\
\text { homophonic } \\
\text { writing in ATB } \\
\text { with occasional } \\
\text { moments of } \\
\text { soprano descant, } \\
\text { then four-part } \\
\text { homophony. } \\
\text { Ending on a Bb } \\
\text { sus4 chord, in } \\
\text { octaves (6-part) }\end{array}$ \\
\hline $\begin{array}{l}\text { mm. 53-59 } \\
(3+4)\end{array}$ & $\begin{array}{l}\text { Slowly, freely } \\
{[4 / 4]} \\
{[2 / 4](\mathrm{m} .53)} \\
{[4 / 4](\mathrm{m} .58-59)}\end{array}$ & & $\begin{array}{l}\text { And "Abba, Father," } \\
\text { cry. } \\
\text { Arise, my soul, arise! }\end{array}$ & $\begin{array}{l}\text { SA statement of } \\
\text { melody with } \\
\text { momentary divisi, } \\
\text { then homophonic } \\
\text { conclusion }\end{array}$ \\
\hline
\end{tabular}

\section{Further Musical Analysis/Considerations}

Arise, My Soul, Arise is among the more straightforward pieces in this set from a musical vantage point. Many of the melodic lines are sung in unison, and the instances of multipart homophony are reserved for climactic moments. There are a few tight harmonies that could present tuning challenges, but most of them occur as passing tones, with a notable exception at m. 51 as seen in Figure 2.

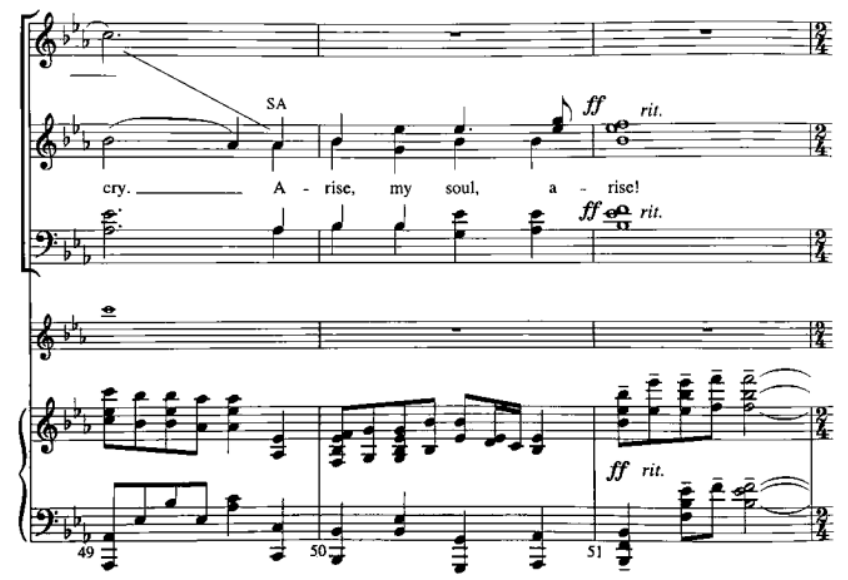

Figure 2: mm. 49-51 of Arise, My Soul, Arise. Notice the line tracing from the violin melody to the soprano line, indicating where the melody falls and how it flows between performing forces. 
The accompaniment is also consistently present and provides enough of a harmonic base so singers should never feel a loss of the tonal anchor. The time signature changes in the middle and toward the end of the piece, which occur in rapid succession, could initially be a point of confusion. It is important for singers to embrace the flow of the text and recognize that in these instances, the meter changes are presented in order to serve the natural text stress, rather than the text being governed by the meter. In Figure 3, notice how the choice of metrical setting results in the word "confidence" beginning on the downbeats of both m. 44 and 45 .

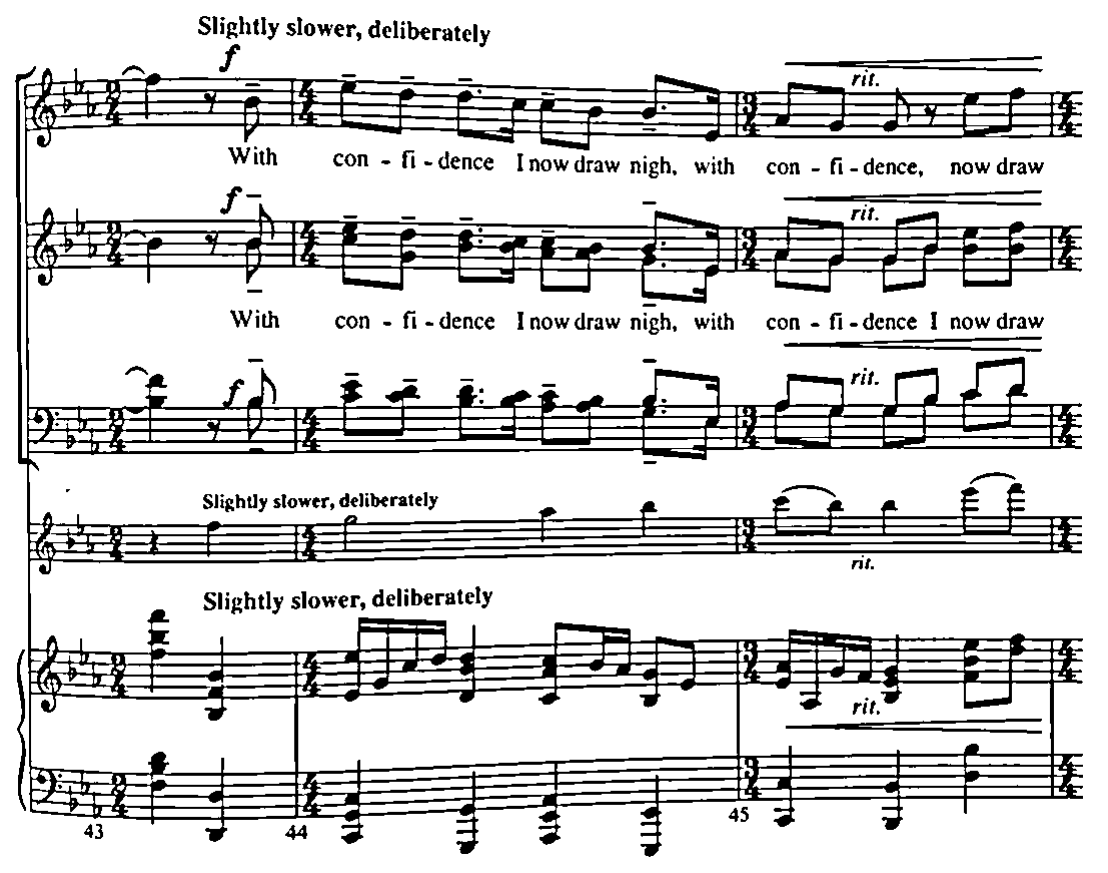

Figure 3: mm. 43-45 of Arise, My Soul, Arise.

A challenge of interpretation will be in the conductor's ability to present the subtle differences in tempi as described by Forrest. At times, the quarter note pulse of this piece equals $60 \mathrm{bpm}$, at other times $56 \mathrm{bpm}$, and at other times $63 \mathrm{bpm}$. Elsewhere, no exact bpm value is presented, and instead an instruction is given such as "Slowly, freely." While it appears as though Forrest is encouraging an interpretation of the piece that takes 
tempo liberties, he also provides several metronome markings that, while fairly similar to one another, are noticeably different enough to conclude Forrest has a fixed and nuanced idea of how quickly this piece should be performed. Moreover, these tempo changes are subtle enough that they require a conductor with a sophisticated sense of timing in order to interpret them as written.

Another unique element of this work is the solo violin. Though stated as optional, it seems to occupy a necessary part of the texture. In instances where the piano and violin play together without the choir, the violin often plays the melody alone. The violin also frequently plays a supporting role when the choir is singing, and herein lies a unique opportunity afforded by this piece. There are moments in this work when the attention should shift to the violin, times when it should shift to the piano, and times when the attention should shift to the choir. None of these forces seem to play a particularly subservient role to the other. It is important to teach the choir how to actively listen to the accompaniment forces and understand both when the choir is the most important component of the overall sound and when the instruments are more important. Learning to participate in something more akin to a duet or trio, rather than as a soloist force with accompanying instruments, is a skill frequently taught in individual voice lessons. This piece provides an opportunity to teach that skill in a choral context. 
Ave Maris Stella by Mark Thomas

Table 5: Basic information for Ave Maris Stella

\begin{tabular}{|l|l|}
\hline Title & Ave Maris Stella \\
\hline Composer & Mark Thomas \\
\hline Publisher & earthsongs \\
\hline Year & 2010 \\
\hline Accompaniment & Piano, opt. violin \\
\hline Tonality & F Major \\
\hline Range & Soprano: C4-Bb5 \\
& Alto: A3-D5 \\
& Tenor: D3-F4 \\
& Bass: G2-C4 \\
& Soloist: D4-G5 \\
\hline Duration & 5:30 \\
\hline Tempo & Serene and deliberate $(d .=c .50)$ \\
\hline
\end{tabular}

Table 6: Score analysis of Ave Maris Stella

\begin{tabular}{|c|c|c|c|}
\hline $\begin{array}{l}\text { Sections, } \\
\text { (Phrase } \\
\text { Groupings) }\end{array}$ & Meter & Text & $\begin{array}{l}\text { Description, } \\
\text { Notes }\end{array}$ \\
\hline $\begin{array}{l}\mathrm{mm} \cdot 1-5 \\
(3+2)\end{array}$ & $\begin{array}{l}(d .=c .50) \\
{[6 / 8]}\end{array}$ & - & $\begin{array}{l}\text { Instrumental } \\
\text { introduction }\end{array}$ \\
\hline $\begin{array}{l}\mathrm{mm} .6-37 \\
(6+5+3+3+8 \\
+4+3)\end{array}$ & $\begin{array}{l}{[\mathbf{9 / 8}](\mathrm{m} .7-8)} \\
{[\mathbf{6 / 8}](\mathrm{m} .9-18)} \\
{[\mathbf{9 / 8}](\mathrm{m} .19)} \\
{[\mathbf{6 / 8}](\mathrm{m} .20-21)} \\
{[\mathbf{9 / 8}](\mathrm{m} .22)} \\
{[\mathbf{6 / 8}](\mathrm{m} .23-)}\end{array}$ & $\begin{array}{l}\text { Ave maris stella, } \\
\text { Dei Mater alma, } \\
\text { Atque semper Virgo, } \\
\text { Felix caeli porta. } \\
\text { Sumens illud Ave } \\
\text { Gabrielis ore, } \\
\text { Funda nos in pace, } \\
\text { Muntans Evae nomen. }\end{array}$ & $\begin{array}{l}\text { First two } \\
\text { stanzas of text, } \\
\text { entirely by } \\
\text { soloist with } \\
\text { accompaniment }\end{array}$ \\
\hline $\begin{array}{l}\mathrm{mm} .38-50 \\
(3+3+4+3)\end{array}$ & & $\begin{array}{l}\text { Solve vincla reis, } \\
\text { Profer lumen caecis, } \\
\text { Mala nostra pelle, } \\
\text { Bona cuncta posce. }\end{array}$ & $\begin{array}{l}\text { Soloist } \\
\text { continues with } \\
\text { addition of } \\
\text { SATB harmony } \\
\text { (+divisi) }\end{array}$ \\
\hline $\begin{array}{l}\mathrm{mm} .51-70 \\
(4+4+5+4+3)\end{array}$ & & $\begin{array}{l}\text { Monstra te esse matrem, } \\
\text { Sumat per te preces, } \\
\text { Qui pro nobis natus } \\
\text { Tulit esse tuus. }\end{array}$ & $\begin{array}{l}\text { Similar as } \\
\text { before, but now } \\
\text { with moments } \\
\text { of choir singing } \\
\text { without soloist }\end{array}$ \\
\hline $\begin{array}{l}\mathrm{mm} .71-83 \\
(3+3+4+3)\end{array}$ & $\begin{array}{l}\text { [9/8] (m.79) } \\
{[\mathbf{6 / 8}](\mathrm{m} .80-)}\end{array}$ & $\begin{array}{l}\text { Virgo singularis, } \\
\text { Inter omnes mitis, }\end{array}$ & $\begin{array}{l}\text { Soprano joins } \\
\text { soloist for some }\end{array}$ \\
\hline
\end{tabular}




\begin{tabular}{|l|l|l|l|}
\hline & & $\begin{array}{l}\text { Nos culpis solutos, } \\
\text { Mites fac et castos. }\end{array}$ & $\begin{array}{l}\text { of melody, } \\
\text { soloist has } \\
\text { individual line } \\
\text { in the middle } \\
\text { section }\end{array}$ \\
\hline $\begin{array}{l}\text { mm. 84-103 } \\
(4+4+5+4+3)\end{array}$ & & $\begin{array}{l}\text { Vitam praesta puram, } \\
\text { Iter para tutum, } \\
\text { Ut videntes Jesum, } \\
\text { Semper collaetemur. }\end{array}$ & $\begin{array}{l}\text { Similar to mm. } \\
51-70, \text { with } \\
\text { different stanza } \\
\text { of text }\end{array}$ \\
\hline $\begin{array}{l}\text { mm. 104-124 } \\
(4+4+5+4+4)\end{array}$ & & $\begin{array}{l}\text { Sit laus Deo Patri, } \\
\text { Summo Christo decus, } \\
\text { Spiritui Sancto, } \\
\text { Tribus honor unus. Amen. }\end{array}$ & $\begin{array}{l}\text { Also similar to } \\
\text { mm. 51-70 with } \\
\text { different text, } \\
\text { also with } \\
\text { greater dynamic } \\
\text { contrast and } \\
\text { higher violin at } \\
\text { climactic } \\
\text { moments }\end{array}$ \\
\hline $\begin{array}{l}\text { mm. 125-131 } \\
(3+4)\end{array}$ & $\begin{array}{l}\text { [9/8] (m.126-127) } \\
{[\mathbf{6 / 8} \text { (m.128-131) }}\end{array}$ & $\begin{array}{l}\text { Ave maris stella. } \\
\text { Simple melodic } \\
\text { statement by } \\
\text { soloist with } \\
\text { accompaniment }\end{array}$ \\
\hline
\end{tabular}

\section{Further Musical Analysis/Considerations}

The most unusual feature of this score is the way meter changes and rhyhms are presented. The work exclusively features compound meters (9/8 and 6/8), but the chorus almost never performs compound rhythms. ${ }^{3}$ Most commonly, the choral parts consist of dotted quarter note rhythms, and shorter rhythms employ duplet or quadruplet notation. Were it not for the piano accompaniment, this work would be more fittingly scored in simple meters. ${ }^{4}$ This would be advisable given the added difficulty encountered by the singers in interpreting compound meter with juxtaposed duplets as opposed to simple

\footnotetext{
${ }^{3}$ A compound rhythm or simple rhythm, as used here, refers to a rhythm that does not require tuplet notation to be performed in a compound or simple meter, respectively. For example, running eighth notes in compound meter will have three notes per pulse, as opposed to two in simple meter. In order to notate two equally long notes per pulse in a compound meter, duplet notation must be employed in the same way triplet notation is employed to evenly divide a pulse between three notes in simple meter.

${ }^{4}$ Switching between $3 / 4$ and 2/4 instead of their compound counterparts, 9/8 and 6/8. In this case, the accompanist's part would be running sextuplets for most of the piece.
} 
meter with occasional triplets. These choral parts also have simple rhythms more frequently than compound rhythms. If this work were scored in simple meter, the accommodations the singers would have to make via triplets and sextuplets would be less than they currently must make via duplets and quadruplets as seen in Figure 4.

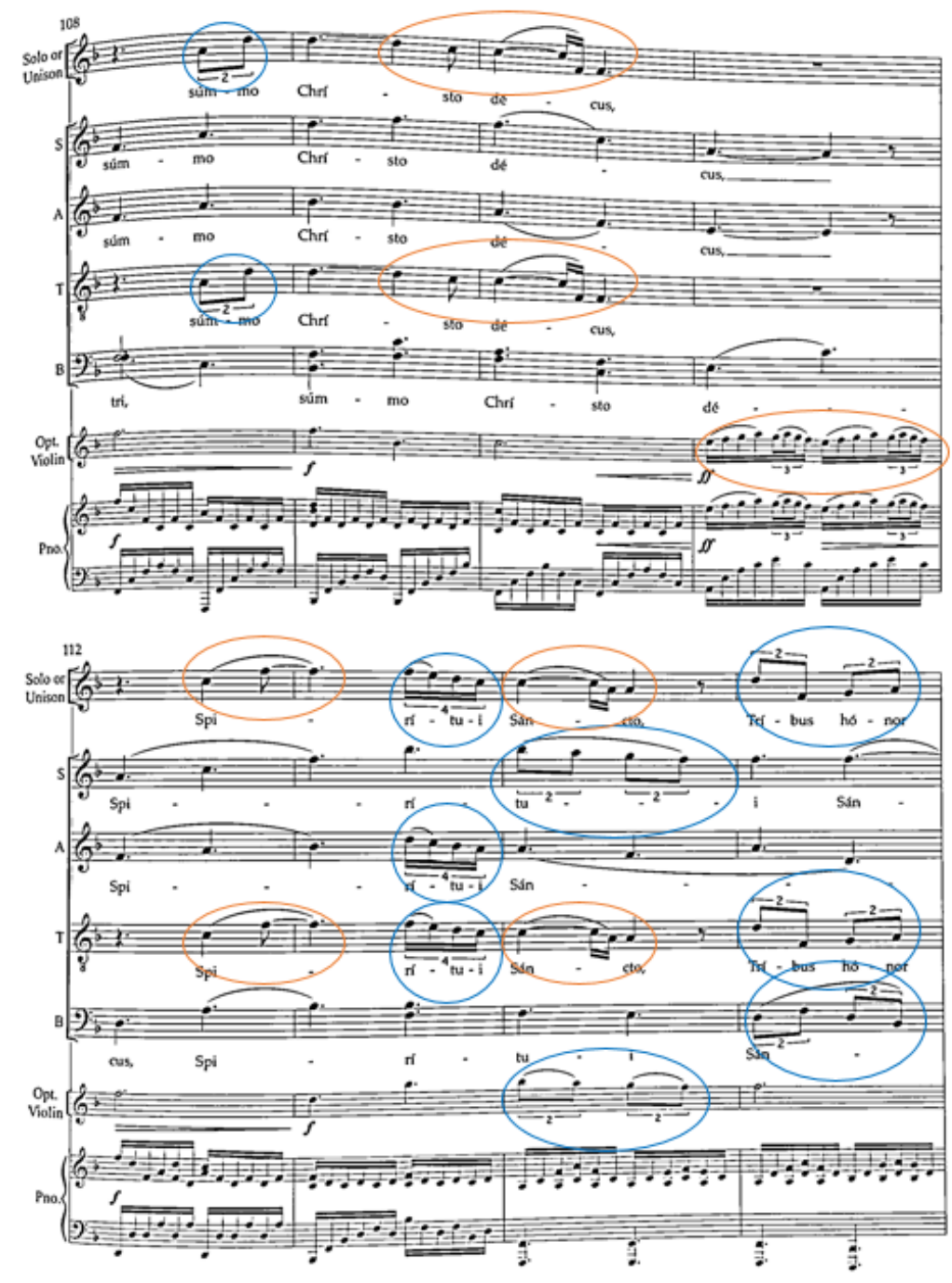

Figure 4: mm. 108-115 of Ave Maris Stella. Compound rhythms are circled in orange, simple rhythms in blue. In this one page sample and throughout the piece, there are more simple rhythms than compound rhythms when excluding the piano accompaniment.

Additionally, there are seven stanzas of Latin, which is a large quantity of text for singers to deal with. Though Latin is a common singing language, these words would not 
be as familiar as those found in other Latin texts to younger singers. Though accompanied by a piano and an optional violin, these instruments provide minimal support in the ensemble context. The running notes do provide a consistent sense of tonal center, which benefits the choir. However, the quick compound rhythms tend to move against the duple feel of the choral parts and makes the rhythmic pulse of the piece feel nebulous. Coordinating the strangely notated rhythms in a clear and helpful way is challenging for the conductor, as is keeping track of the frequent meter changes in the soloist section. Of this set of seven pieces, this one is possibly the most challenging from a conducting perspective for this reason. 


\section{This is the Day by Keith Hampton}

Table 7: Basic information for This is the Day

\begin{tabular}{|l|l|}
\hline Title & This is the Day \\
\hline Composer & Keith Hampton \\
\hline Publisher & earthsongs \\
\hline Year & 2019 \\
\hline Accompaniment & Piano, ad lib. electric bass guitar and drum set \\
\hline Tonality & F Major \\
\hline Range & Soprano: F4-G5 \\
& Alto: D4-Db5 \\
& Tenor: F3-G4 \\
& Bass: A2-D4 \\
& S soloist: C4-G5 \\
& A soloist: C4-D5 \\
& T soloist: Ab3-A4 \\
& B soloist: B3-D4 \\
\hline Duration & 3:45 \\
\hline Tempo & $($ d=c.96-98) \\
\hline Meter & {$[4 / 4]$} \\
\hline
\end{tabular}

Table 8: Score analysis of This is the Day

\begin{tabular}{|c|c|c|c|}
\hline $\begin{array}{l}\text { Sections, } \\
\text { (Phrase } \\
\text { Groupings) }\end{array}$ & Tonality & Text & Description, Notes \\
\hline $\begin{array}{l}\mathrm{mm} \cdot 1-7 \\
(3+4)\end{array}$ & F Major & - & $\begin{array}{l}\text { Instrumental } \\
\text { introduction }\end{array}$ \\
\hline $\begin{array}{l}\mathrm{mm} .8-13 \\
(2+2+2)\end{array}$ & & $\begin{array}{l}\text { This is the day the Lord has } \\
\text { made. } \\
\text { Let us rejoice, be glad in it. }\end{array}$ & $\begin{array}{l}\text { "A" statement by } \\
\text { the choir with lead- } \\
\text { in by the soloist }\end{array}$ \\
\hline $\begin{array}{l}\mathrm{mm} .14-28 \\
(2+2+2+4+4)\end{array}$ & & $\begin{array}{l}\text { (refrain) Oh, enter His gates } \\
\text { with thanksgiving, } \\
\text { Enter his courts with praise. } \\
\text { Just give thanks to Him. } \\
\text { Just praise His name, for the } \\
\text { Lord is good and His love never } \\
\text { ends. (refrain) Open for me the } \\
\text { gates of the righteous; come in } \\
\text { give thanks to God. } \\
\text { Oh, give thanks to God, for He } \\
\text { is good; and His love endures } \\
\text { forevermore. }\end{array}$ & $\begin{array}{l}\text { Repeated section } \\
\text { with choral "A" } \\
\text { statements flanking } \\
\text { solo sections }\end{array}$ \\
\hline
\end{tabular}




\begin{tabular}{|c|c|c|c|}
\hline $\begin{array}{l}\mathrm{mm} .29-34 \\
(2+2+2)\end{array}$ & & (refrain) & $\begin{array}{l}\text { Choral "A" } \\
\text { statement }\end{array}$ \\
\hline $\begin{array}{l}\mathrm{mm} \cdot 35-45 \\
(3+4+4)\end{array}$ & Ab Major & $\begin{array}{l}\text { Rejoice! Be glad! } \\
\text { This is the day of the Lord! }\end{array}$ & $\begin{array}{l}\text { Beginning of vamp } \\
\text { section with claps. } \\
\text { Choir trading two- } \\
\text { bar phrases with } \\
\text { soloists }\end{array}$ \\
\hline $\begin{array}{l}\mathrm{mm} \cdot 46-53 \\
(4+4)\end{array}$ & A Major & $\begin{array}{l}\text { Rejoice! Be glad! } \\
\text { This is the day of the Lord! }\end{array}$ & $\begin{array}{l}\text { As before, with an } \\
\text { additional } \\
\text { ascending half-step } \\
\text { modulation }\end{array}$ \\
\hline $\begin{array}{l}\mathrm{mm} .54-61 \\
(4+4)\end{array}$ & $\mathrm{Bb}$ Major & $\begin{array}{l}\text { Rejoice! Be glad! } \\
\text { This is the day of the Lord! }\end{array}$ & $\begin{array}{l}\text { As before, with } \\
\text { another modulation }\end{array}$ \\
\hline $\begin{array}{l}\mathrm{mm} \cdot 62-73 \\
(4+4+4)\end{array}$ & & $\begin{array}{l}\text { Rejoice! Be glad! } \\
\text { This is the day of the Lord! }\end{array}$ & $\begin{array}{l}\text { New choral } \\
\text { material, "rejoice" } \\
\text { in stratified } \\
\text { entrances }\end{array}$ \\
\hline $\begin{array}{l}\mathrm{mm} .74-83 \\
(2+2+2+2+4)\end{array}$ & G Major & (refrain) & $\begin{array}{l}\text { Return of the choral } \\
\text { "A" material, new } \\
\text { music for final few } \\
\text { measures }\end{array}$ \\
\hline
\end{tabular}

\section{Further Musical Analysis/Considerations}

One of the major challenges throughout this work is the frequency of syncopated rhythms. Though they make sense in a listening context, the rhythms are not easy to decipher in their notated form, and this can lead this music to feel rhythmically clunky or jagged. As will be discussed in the next section, this work could benefit from incorporating an aural form of teaching, as opposed to written. It will also take time to coordinate the clapping, as that feature begins early and continues for much of the piece. The tendency with this clapping will be to speed up, especially considering how rapid the claps are. Keith Hampton takes care to provide step-by-step suggestions on teaching this particular aspect of the music in his notes for the piece, as can be seen in Figure 5. 
The B section is called the vamp section or-in the Black chunch-the special section. Be sure to practice the claps while the piano plays at a slower tempo. Strive to execute the claps in sync with the piano part. This is called the "groove." for rehearsil purposes, I suggest:

1. claps and piano without singing.

2. claps and singing accompanied by the piano at a slower tempo.

3. While maintaining the "groove", increase the tempo.

When clapping, hold one hand stationary as if a hand drum. Use the other hand to strike the stationary one.

Figure 5: Note by Keith Hampton on the back page of This is the Day.

The conductor will also have to coordinate the addition of an instrumental rhythm section consisting of drums and electric bass. It will be necessary to provide sufficient guidance to these musicians, as they have no explicitly notated parts. Finally, unlike other works in this collection, This is the Day features frequent modulations by ascending half steps. Though these modulations keep the vocal ranges in a relatively consistent tessitura, they result in some melodic ideas being reiterated in harmonically distant keys. This is not a particularly difficult modulation to teach, though it might prove challenging for singers who struggle to conceptualize intervals from slightly, though discernably different tonal starting points. 


\section{Bright Morning Stars arr. Shawn Kirchner}

Table 9: Basic information for Bright Morning Stars

\begin{tabular}{|l|l|}
\hline Title & Bright Morning Stars \\
\hline Composer & Traditional Appalachian song, arr. Shawn Kirchner \\
\hline Publisher & Santa Barbara Music Publishing, Inc. \\
\hline Year & 2005 \\
\hline Accompaniment & Piano \\
\hline Tonality & B Major \\
\hline Range & Soprano: B3-G\#5 \\
& Alto: A\#3-D\#5 \\
& Tenor: C\#3-F\#4 \\
& Bass: F\#2-D\#4 \\
& Soloist: D\#3-D\#4 \\
\hline Duration & 5:30 \\
\hline
\end{tabular}

Table 10: Score analysis of Bright Morning Stars

\begin{tabular}{|c|c|c|c|}
\hline $\begin{array}{l}\text { Sections, } \\
\text { (Phrase } \\
\text { Groupings) }\end{array}$ & Tempo, [Meter] & Text & Description, Notes \\
\hline $\begin{array}{l}\mathrm{mm} .1-18 \\
(5+2+4+3+4)\end{array}$ & $\begin{array}{l}\text { Simply and } \\
\text { soulfully } \\
(d=\text { ca.60) } \\
{[4 / 4]} \\
{[3 / 4](\mathrm{m} .8)} \\
{[2 / 4](\mathrm{m} .9)} \\
{[3 / 4](\mathrm{m} .10-18)}\end{array}$ & $\begin{array}{l}\text { Bright morning stars } \\
\text { are rising, } \\
\text { Day is a-breaking in } \\
\text { my soul. }\end{array}$ & $\begin{array}{l}\text { B solo, choral entrance } \\
\text { on "Oo," all over } \\
\text { accompaniment }\end{array}$ \\
\hline $\begin{array}{l}\mathrm{mm} \cdot 19-27 \\
(4+2+3)\end{array}$ & $\begin{array}{l}{[\mathbf{4 / 4}]} \\
{[3 / 4](\mathrm{m} .25)} \\
{[2 / 4](\mathrm{m} .26)} \\
{[3 / 4](\mathrm{m} .27)}\end{array}$ & $\begin{array}{l}\mathrm{O} \text { where are our dear } \\
\text { fathers? } \\
\text { Day is a-breaking in } \\
\text { my soul. }\end{array}$ & $\begin{array}{l}\text { A cappella 4-part TTBB, } \\
\text { homophonic }\end{array}$ \\
\hline $\begin{array}{l}\mathrm{mm} .28-38 \\
(4+2+3+2+2)\end{array}$ & $\begin{array}{l}\text { Più mosso } \\
(d=68-72) \\
{[4 / 4]} \\
{[3 / 4](\mathrm{m} .34)} \\
{[2 / 4](\mathrm{m} .35)} \\
{[3 / 4](\mathrm{m} .36-50)}\end{array}$ & $\begin{array}{l}\text { They are down in the } \\
\text { valley praying, } \\
\text { Day is a-breaking in } \\
\text { my soul. }\end{array}$ & $\begin{array}{l}\text { Piano re-enters, TTBB } \\
\text { cuts out, 2-part S and A } \\
\text { enter, polyphonic }\end{array}$ \\
\hline $\begin{array}{l}\mathrm{mm} \cdot 39-50 \\
(2+2+4+2)\end{array}$ & & - & Piano interlude \\
\hline $\begin{array}{l}\mathrm{mm} \cdot 51-60 \\
(4+2+4)\end{array}$ & $\begin{array}{l}\text { Solemnly } \\
(d=60) \\
{[4 / 4]}\end{array}$ & $\begin{array}{l}\text { O where are our dear } \\
\text { mothers? } \\
\text { Day is a-breaking in } \\
\text { my soul. }\end{array}$ & $\begin{array}{l}\text { Re-entry of SATB choir, } \\
\text { 4-part, homophonic }\end{array}$ \\
\hline
\end{tabular}




\begin{tabular}{|c|c|c|c|}
\hline & $\begin{array}{l}\text { Poco movendo } \\
(\mathrm{m} .54) \\
{[3 / 4](\mathrm{m} .57)} \\
{[2 / 4](\mathrm{m} .58)} \\
{[3 / 4](\mathrm{m} .59-60)}\end{array}$ & & \\
\hline $\begin{array}{l}\mathrm{mm} .61-72 \\
(4+2+3+3)\end{array}$ & $\begin{array}{l}\text { a tempo } \\
{[4 / 4]} \\
{[3 / 4](\mathrm{m} .67-72)}\end{array}$ & $\begin{array}{l}\text { They have gone to } \\
\text { heaven shouting, } \\
\text { Day is a-breaking in } \\
\text { my soul. }\end{array}$ & $\begin{array}{l}\text { TB unison melody, } S \text { and } \\
\text { A continue }\end{array}$ \\
\hline $\begin{array}{l}\mathrm{mm} .73-84 \\
(4+2+6)\end{array}$ & $\begin{array}{l}\text { With wonder } \\
\text { [4/4] } \\
{[3 / 4](\mathrm{m} .79-83)} \\
{[4 / 4](\mathrm{m} .84-90)}\end{array}$ & $\begin{array}{l}\text { O where are our dear } \\
\text { children? } \\
\text { They're upon the } \\
\text { earth a-dancing, } \\
\text { Day is a-breaking in } \\
\text { my soul. }\end{array}$ & $\begin{array}{l}\text { AB melody in octaves, } \mathrm{S} \\
\text { and T have staggered } \\
\text { entrances with similar } \\
\text { rhythms }\end{array}$ \\
\hline $\begin{array}{l}\operatorname{mm} .85-95 \\
(4+2+5)\end{array}$ & $\begin{array}{l}{[3 / 4](\mathrm{m} .91)} \\
{[2 / 4](\mathrm{m} .92)} \\
{[3 / 4](\mathrm{m} .93-95)}\end{array}$ & $\begin{array}{l}\text { Bright morning stars } \\
\text { are rising, } \\
\text { Day is a-breaking in } \\
\text { my soul. }\end{array}$ & $\begin{array}{l}\text { Return of B soloist, } \\
\text { SATB on octave hum }\end{array}$ \\
\hline
\end{tabular}

\section{Further Musical Analysis/Considerations}

Tonally speaking, this is the simplest piece of the set. The parts largely abide by the pentatonic scale, and there are no instances of notes outside the B major pitch collection in any of the vocal parts. In fact, there are only five incidences of accidentals in the entire work, and they all occur in the accompaniment between mm. 33 and 43 . The meter changes, though frequent, occur in a predictable pattern on the same text and in the same way each time as seen in Figure 6, "Day is a-breaking in my soul."

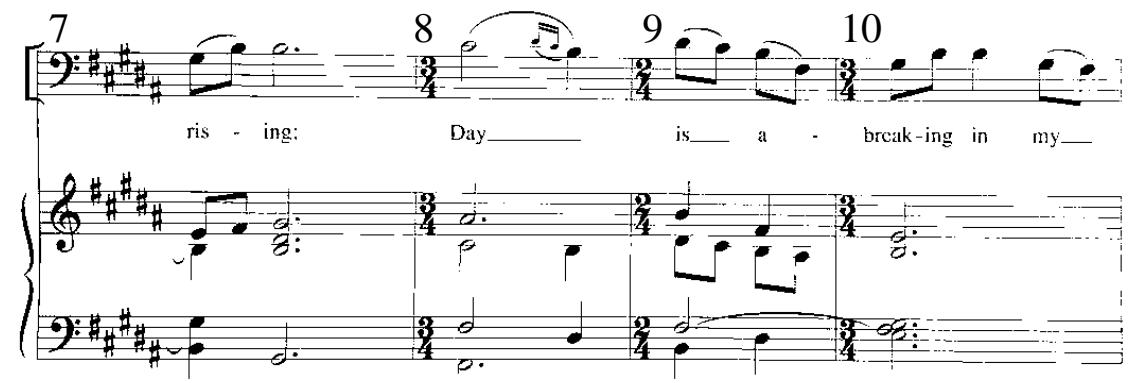

Figure 6: mm. 7-10 of Bright Morning Stars. 
One section that could provide a challenge is $\mathrm{mm} .19-27$, where the TTBB voices echo the soloist in four-part homophony. There are few other instances in this set of repertoire wherein the TTBB voices are divided into four parts. Depending on the size of the choir, it could take some work to overcome the challenge of individual ownership of the multiple parts. Moreover, this section is performed a cappella, with the piano promptly rejoining after the soprano anacrusis into section three. If the TTBB voices go out of tune in these eight measures, that change would become immediately evident at $\mathrm{m} .28$ once the piano rejoins along with the other voices.

About one fourth of this piece is the soloist material at the opening and ending. The melody sung in the beginning by the soloist is the same one echoed in each subsequent verse of text. As such, selecting a reliable baritone soloist is of critical importance for the success of this piece's performance. The melody is not challenging musically, and in terms of range it should be attainable by either a tenor or bass. Many students should be able to sing this melody, and determining which singer will perform it the most reliably and believably is a task that should be undertaken with due diligence. 


\section{Arirang arr. Hyo-Won Woo}

Table 11: Basic information for Arirang

\begin{tabular}{|l|l|}
\hline Title & 아리랑 (Arirang) \\
\hline Composer & Traditional Korean, arr. Hyo-Won Woo (b. 1974) \\
\hline Publisher & Walton \\
\hline Year & 2018 \\
\hline Accompaniment & Piano, Korean Percussion (Buk and Ggoenggwari) \\
\hline Tonality & G Major (mm. 1-50), Ab Major (mm. 51-142) \\
\hline Range & $\begin{array}{l}\text { Soprano: D4-Bb5 } \\
\text { Alto: A3-F5 } \\
\text { Tenor: D3-Ab4 } \\
\text { Bass: C3- Eb4 }\end{array}$ \\
\hline Duration & $4: 45$ \\
\hline
\end{tabular}

Table 12: Score analysis of Arirang

\begin{tabular}{|c|c|c|c|c|}
\hline $\begin{array}{l}\text { Sections, } \\
\text { (Phrase } \\
\text { Groupings) }\end{array}$ & $\begin{array}{l}\text { Tempo, } \\
\text { [Meter] }\end{array}$ & Tonality & Text & Description, Notes \\
\hline $\begin{array}{l}\text { mm. 1-9 } \\
(4+5)\end{array}$ & $\begin{array}{l}\text { Andantino } \\
(d=\text { ca. } 80) \\
{[3 / 4]}\end{array}$ & G Major & - & $\begin{array}{l}\text { Piano introduction, } \\
\text { employment of non- } \\
\text { chord tones in LH at } \\
\text { m. } 7\end{array}$ \\
\hline $\begin{array}{l}\mathrm{mm} .10-25 \\
(4+4+4+4)\end{array}$ & & & $\begin{array}{l}\text { Arirang, arirang, } \\
\text { arariyo } \\
\text { Arirang gogaero } \\
\text { neomuhganda } \\
\text { Nareul beorigo gasi } \\
\text { neun nimeun } \\
\text { Simridoh motgaseo } \\
\text { balbbyong nanda }\end{array}$ & $\begin{array}{l}\text { Unison melody } \\
\text { (SA). All notes of } \\
\text { the melody are in the } \\
\text { major pentatonic } \\
\text { scale }\end{array}$ \\
\hline $\begin{array}{l}\mathrm{mm} .26-33 \\
(4+4)\end{array}$ & & & - & Piano interlude \\
\hline $\begin{array}{l}\mathrm{mm} .34-50 \\
(4+4+4+5)\end{array}$ & & & $\begin{array}{l}\text { Arirang, arirang, } \\
\text { arariyo } \\
\text { Arirang gogaero } \\
\text { neomuhganda } \\
\text { Nareul beorigo gasi } \\
\text { neun nimeun } \\
\text { Simridoh motgaseo } \\
\text { balbbyong nanda }\end{array}$ & $\begin{array}{l}\text { Melody in parallel } \\
\text { octaves, SA together } \\
\& \text { TB together (mm. } \\
34-41) \text {, then voices } \\
\text { split into } \\
\text { homophonic four- } \\
\text { part harmony, end } \\
\text { on octave G (mm. } \\
42-50)\end{array}$ \\
\hline
\end{tabular}




\begin{tabular}{|c|c|c|c|c|}
\hline $\begin{array}{l}\mathrm{mm} \cdot 51-66 \\
(4+4+4+4)\end{array}$ & & Ab Major & $\begin{array}{l}\text { Arirang, arirang, } \\
\text { arariyo } \\
\text { Arirang gogaero } \\
\text { neomuhganda } \\
\text { Nareul beorigo gasi } \\
\text { neun nimeun } \\
\text { Simridoh motgaseo } \\
\text { balbbyong nanda }\end{array}$ & $\begin{array}{l}\text { Two-part melody in } \\
\text { octaves, ST together } \\
\text { and AB together, } \\
\text { now in Ab Major }\end{array}$ \\
\hline $\begin{array}{l}\mathrm{mm} \cdot 67-73 \\
(4+3)\end{array}$ & & & - & Piano interlude \\
\hline $\begin{array}{l}\mathrm{mm} \cdot 74-77 \\
\text { (4) }\end{array}$ & $\begin{array}{l}\text { Allegro } \\
(d=\text { ca. } 152) \\
{[4 / 4]}\end{array}$ & & - & $\begin{array}{l}\text { Addition of Korean } \\
\text { percussion (Buk \& } \\
\text { Ggoenggwari). } \\
\text { Though notated as } \\
4 / 4 \text {, this section } \\
\text { presents more of an } \\
8 / 8 \text { feeling }(3+3+2)\end{array}$ \\
\hline $\begin{array}{l}\mathrm{mm} .78-93 \\
(4+4+4+4)\end{array}$ & & & $\begin{array}{l}\text { SA: } \\
\text { Ari arirang sseuri } \\
\text { sseurirang ari } \\
\text { arariyo } \\
\text { Ari arari nanne } \\
\text { TB: } \\
\text { Arirang, arirang, } \\
\text { arariyo } \\
\text { Arirang gogaero } \\
\text { neomuhganda } \\
\text { Nareul beorigo gasi } \\
\text { neun nimeun } \\
\text { Simridoh motgaseo } \\
\text { balbbyong nanda }\end{array}$ & $\begin{array}{l}\text { Two-part melody, } \\
\text { SA together and TB } \\
\text { together (mm. } 78- \\
\text { 85), then same two } \\
\text { parts divide into } \\
\text { harmonies (mm. 86- } \\
93 \text { ) }\end{array}$ \\
\hline $\begin{array}{l}\mathrm{mm} \cdot 94-109 \\
(4+4+4+4)\end{array}$ & & & $\begin{array}{l}\text { (Same as previous } \\
\text { section) }\end{array}$ & $\begin{array}{l}\text { TB return to unison, } \\
\text { move on different } \\
\text { beats than SA }\end{array}$ \\
\hline $\begin{array}{l}\mathrm{mm} .110-119 \\
(4+4)\end{array}$ & & & $\begin{array}{l}\text { Arirang, arirang, } \\
\text { arariyo } \\
\text { Arirang gogaero } \\
\text { neomuhganda }\end{array}$ & $\begin{array}{l}\text { Dense divisi in } \\
\text { statement of the } \\
\text { primary text that is } \\
\text { now homophonic. } \\
\text { Repeats itself and } \\
\text { has a soprano } \\
\text { descant featured in } \\
\text { the second iteration }\end{array}$ \\
\hline $\begin{array}{l}\text { mm. 120-135 } \\
(2+2+4+2+2 \\
+4)\end{array}$ & & & $\begin{array}{l}\text { Ari arirang sseuri } \\
\text { sseurirang ari } \\
\text { arariyo } \\
\text { Arari arari nanne }\end{array}$ & $\begin{array}{l}\text { Voices trade } \\
\text { measures with } \\
\text { percussion initially, }\end{array}$ \\
\hline
\end{tabular}




\begin{tabular}{|c|c|c|c|}
\hline & & & $\begin{array}{l}\text { then trade between } \\
\text { SA and TB }\end{array}$ \\
\hline $\begin{array}{l}\mathrm{mm} .136-142 \\
(3+3)\end{array}$ & \begin{tabular}{|l} 
slowly, rit. \\
(m.138) \\
into a \\
tempo \\
$(\mathrm{m} .139)$
\end{tabular} & Ari ari arariyo & $\begin{array}{l}\text { End of consistent } \\
3+3+2 \text { feel, freer } \\
\text { with tempo until } \\
\text { held note at m. } 139 \\
\text { coming out of rit. to } \\
\text { the end }\end{array}$ \\
\hline
\end{tabular}

\section{Further Musical Analysis/Considerations}

Arirang provides its text in four forms, as presented in Figure 7. In addition to the original Korean, the edition also provides the text in two ways intended to aid in pronunciation: a Romanized version and an IPA translation. Then, the piece provides an English translation of the text, line by line for poetic understanding.

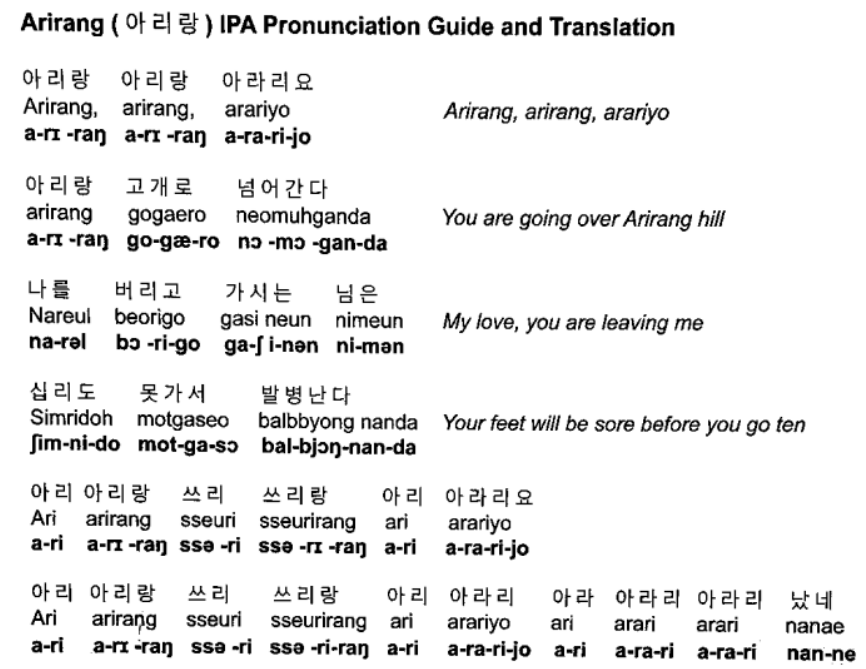

Figure 7: IPA Pronunciation Guide and Translation for Arirang (taken from the first page of the piece).

The metrical labelling of the second half of Arirang (mm. 74-142, after the tempo change) as $4 / 4$ is misleading when considering the true rhythmic foundation of the section. Instead of feeling four equally divided quarter note pulses, this section would be more usefully defined by additive groupings of eighth notes, with the recurring beat pattern being $3+3+2$. This is demonstrated in the beaming patterns of the accompaniment 
as well as the percussion accents that, as shown in Figure 8, emphasize beat 1 , the $\&$ of 2 , and beat 4 after the tempo change.

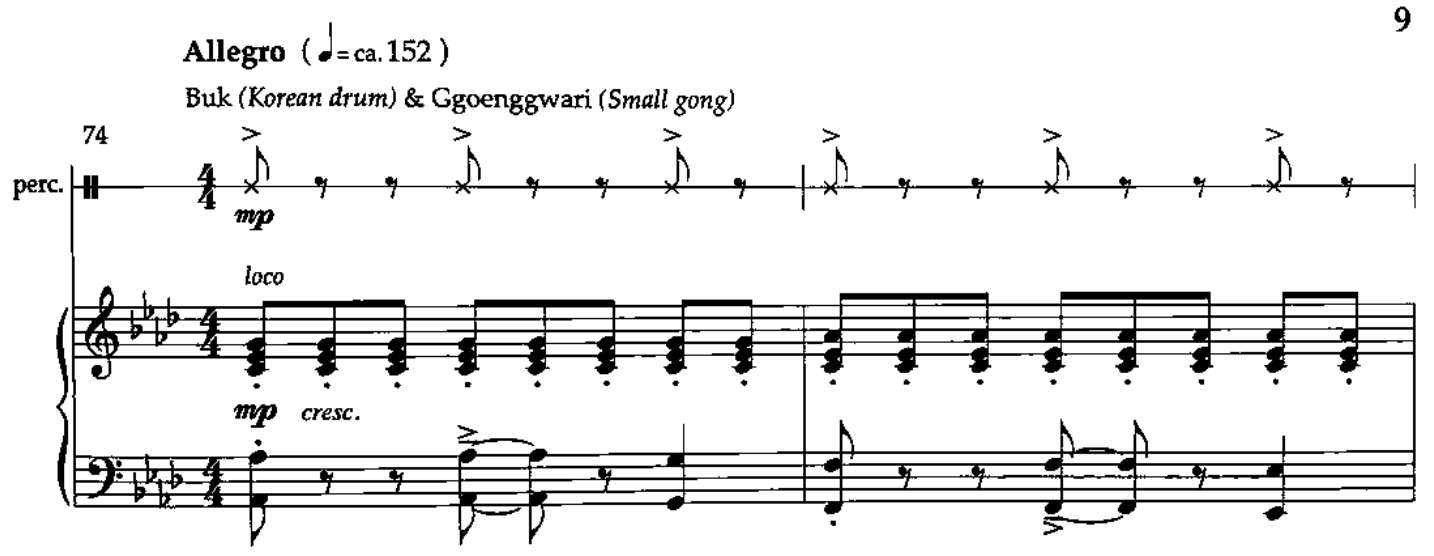

Figure 8: mm. 74-75 of Arirang. Notice the groupings of notes in the piano RH, as well as the accented beats of the percussion part.

4/4 is a more common time signature, and might be simpler to transition into coming from 3/4, as singers would continue watching for a quarter-note pulse. However, the new tempo and meter is established first by four bars of instrumental interlude. There are sections in the second half where the TB voices provide a countermelody that is easier to perform in a 4/4 context, though these are the only instances where a four-beat division of the measure makes the most sense. Even during those moments, the SA voices, percussion, and piano accompaniment are all continuing in the $3+3+2$ pulse pattern, as seen in Figure 9. 


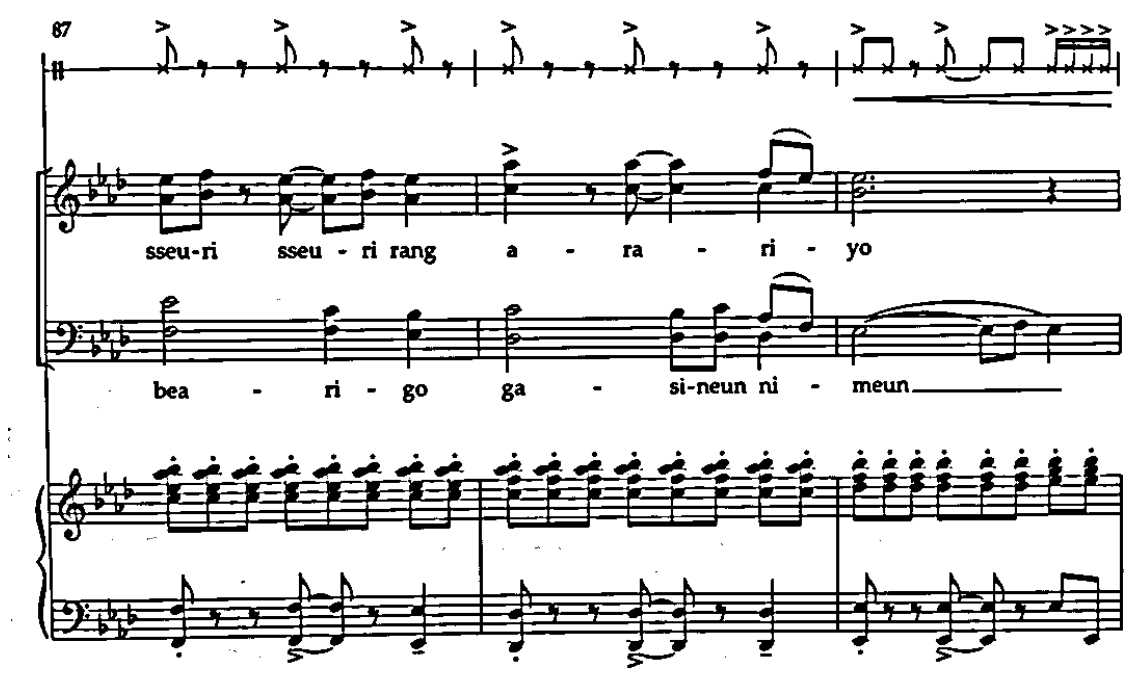

Figure 9: mm. 87-90 of Arirang. The TB voices work well in a 4/4 context, but the rest of the ensemble benefits more from the $3+3+2$ context.

Conducting this section in a 3-pattern with two beats of 3 followed by one beat of 2 is more difficult than four equally divided beats of $4 / 4$. However, teaching the main melodic figures of this section, some of which are awkwardly beamed to account for the 4/4 meter, will be more difficult to do with proper emphases if the conductor rigidly follows such a pattern. If the three-pattern is chosen, students should be encouraged to write in $(3+3+2)$, if scores are not provided with such a marking already inscribed. 


\section{Libertango arr. Oscar Escalada}

Table 13: Basic information for Libertango

\begin{tabular}{|c|c|}
\hline Title & Libertango \\
\hline Composer & Astor Piazzolla, arr. Oscar Escalada \\
\hline Publisher & Neil A. Kjos Music Company \\
\hline Year & 1975 (arr. 2000) \\
\hline Accompaniment & Piano \\
\hline Tonality & A Minor \\
\hline Range & $\begin{array}{l}\text { Soprano: C4-A5 } \\
\text { Alto: B3-D5 } \\
\text { Tenor: B2-G4 } \\
\text { Bass: A2-E4 }\end{array}$ \\
\hline Duration & $2: 30$ \\
\hline Tempo & Deciso $(d=131)$ \\
\hline Meter & {$[4 / 4]$} \\
\hline
\end{tabular}

Table 14: Score analysis of Libertango

\begin{tabular}{|l|l|}
\hline Sections, (Phrase Groupings) & Description, Notes \\
\hline $\begin{array}{l}\mathrm{mm} .1-16 \\
(4+4+4+4)\end{array}$ & Main melody in ATB voices \\
\hline $\begin{array}{l}\mathrm{mm} .17-32 \\
(4+4+4+4)\end{array}$ & ATB repeat, add S descant \\
\hline $\begin{array}{l}\mathrm{mm} .33-48 \\
(4+4+4+4)\end{array}$ & $\begin{array}{l}\text { TB and piano switch roles, S and A have } \\
\text { countermelody on top }\end{array}$ \\
\hline $\begin{array}{l}\mathrm{mm} .49-64 \\
(4+4+4+4)\end{array}$ & $\begin{array}{l}\text { Dynamic section, begins with T melody, then has } \\
\text { distinct } 8^{\text {th }} \text {-note figures in all voices }\end{array}$ \\
\hline $\begin{array}{l}\mathrm{mm} .65-72 \\
(4+4)\end{array}$ & $\begin{array}{l}\text { Return of beginning main melody in SATB voices, } \\
\text { gradually quieting }\end{array}$ \\
\hline $\begin{array}{l}\mathrm{mm} .73-77 \\
(3+2)\end{array}$ & Coda \\
\hline
\end{tabular}

\section{Further Musical Analysis/Considerations}

The repetitiveness of this work can either be of benefit or detriment to the choir, depending on how it is treated by the director. The three lower voices perform the same eight bar phrase in octaves, with some variations toward the end of the piece. As singers become familiar with the repetitiveness of the score, they may cease paying close attention and thus miss changes at critical moments in the music. Moreover, when young 
singers are told to sing an ostinato phrase, the tendency is for their performance to become uninteresting over time. Adhering to the subtle details in these repetitive phrases, such as accents and other articulation markings, should be encouraged to provide students with an artistic goal to work toward. Encouraging dramatic dynamic fluctuations in the penultimate section (Figure 10) can mark the difference between an uninteresting or engaging performance.

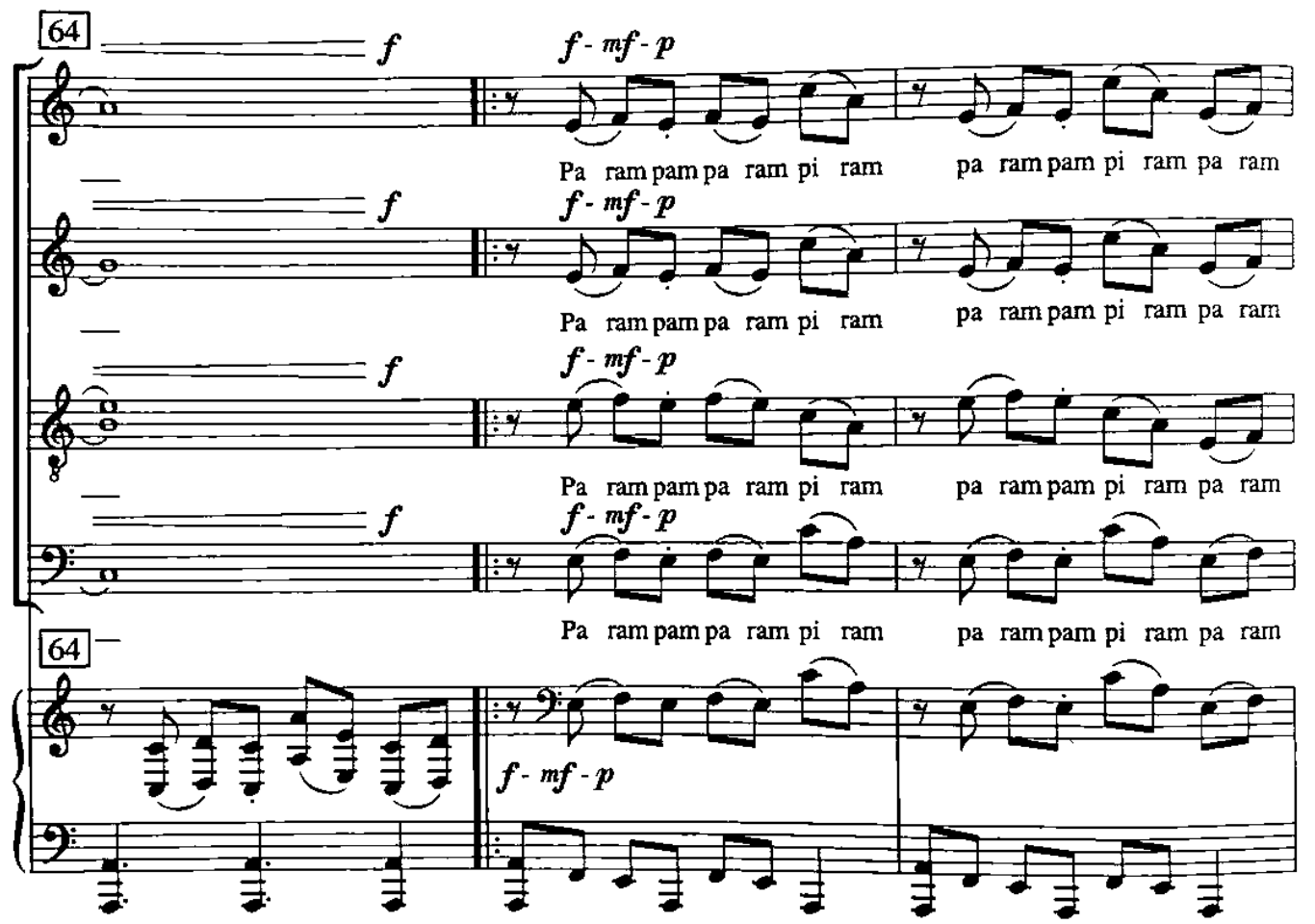

Figure 10: mm. 64-66 of Libertango.

Less energy will be spent on diction since there is no text, though performing the vocables in the precise manner intended by Escalada will still require some work (Figure 11). Due to the repetitive nature of the work, the conductor might encourage the students to memorize some or all of their parts, even if scores are to be used during performance. The form is simple enough that memorizing would not be too challenging for the 
students, and once they remove scores from their sight they will begin to listen to and perform the music with a different sense of understanding. This work provides an excellent opportunity for students to conceptualize music from a broader perspective than simply reading notes one bar at a time.

SPANISH PRONUNCIATION GUIDE

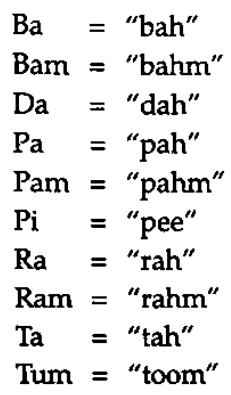

Figure 11: "Spanish pronunciation guide" for Libertango vocables. 


\section{CHAPTER 4: DISCUSSION}

\section{Teaching new languages}

One of the major obstacles of preparing music from other cultures is teaching new languages. To perform well in a foreign language, an ensemble needs not only a baseline of correct pronunciation, but also an understanding of language flow. Even foreign languages similar to English pose challenges to younger choirs. Music in languages increasingly dissimilar from English will seem increasingly inaccessible. This collection of repertoire navigates the language challenge well, only making the choir learn one nonWestern language. Arirang is the only piece in a non-Western language, and there is a minimal amount of Korean text, as the lines are repetitive. Two of the pieces from outside the Western art music canon are from English-language traditions, Bright Morning Stars and This is the Day. The other piece in this category is Libertango, and this piece avoids the language challenge by consisting entirely of vocables meant to imitate instruments. The editions of Libertango and Arirang also provide pronunciation guides. Although all four of these works are from outside the Western art music canon, only one of them demands the choir to learn words in a new language, and minimally so.

This is not to say teaching unfamiliar languages is always a challenge to be avoided. Linguistic nuances are an intrinsically valuable aspect of culture. However, with the amount of time that would be reasonably allocated to the music in a concert set, it is useful to consider ways to introduce cultures without constantly invoking the challenge of 
language teaching. The options explored by this set are preferable to teaching foreign music that has been errantly translated into singable English, a common practice among older editions. This program also allows more time for nuanced exploration of the Korean language than if the set included more foreign languages.

\section{Focus on Arirang: Paying due diligence to the most unfamiliar piece}

When structuring a concert program, varying the difficulty level among pieces can ensure students experience an appropriate balance of music that provides them opportunities for success and growth. Not every piece should be too difficult; neither should the pieces be too simple. This concept is true both for musical difficulty as well as difficulty in grasping cultural understanding. In programming music from a variety of cultures, some are bound to be less accessible than others. In the case of this collection of pieces, this balancing of more and less culturally distant works is present. Of the seven works, Arirang presents the most unfamiliar elements to a typical American music classroom. To perform any of these pieces well, it is essential to grasp the culture well, and in the case of Arirang this would require more devoted time than any of the other six works. This time commitment both comes through the research and preparation done by the music teacher as well as the time spent communicating this information effectively and concisely to the class.

Though the amount of Korean text is minimal, Arirang still provides the most phonetically dissimilar sounds to English of this repertoire, so ensuring that sufficient time is spent working toward accurate pronunciation is important. Korea has a relatively young history of choral music, as it was only introduced there around the end of the 
nineteenth century. However, it has a rich and long-standing history of traditional music, which has provided much source material and information for those choirs seeking to perform in that cultural tradition. Nationalism is particularly important in the Korean cultural tradition, and this fact is reflected in the compositional techniques of Korean composers. As evidence of this, one third of all works performed at the fall 2019 Korean Choral Directors Association Conference incorporated traditional Korean elements (Lee, 2020, p. 63). In the case of Arirang, understanding the significance of incorporating Korean rhythms, modes, and instruments is essential to fulfilling the full educational potential of the work.

Focusing research efforts on the most unfamiliar piece does not only work to bridge the cultural gap, it also provides a greater understanding for the compositional process. For instance, like many other folk music traditions from around the world, traditional Korean music prominently features the pentatonic collection; Do, Re, Mi, Sol, and $\mathrm{La}$. A unique aspect of this music, however, is that songs frequently modify the starting point in that collection of five notes, each version with its own name. The Pyongjo (sol mode: sol-la-do-re-mi) and Kyemyon-jo (la mode: la-do-re-mi-sol) sequences are the most common. Although most Korean music uses pentatonic modes, some uses 3, 4, or 6 note modes (Korea National Gugak Center).

Rhythmically, all traditional Korean songs begin on a downbeat, and this is reflected in the lack of anacruses in this edition. The syntactic rationale for this feature is that the Korean language utilizes postpositions instead of prepositions. Therefore, the noun, gerund, or clause modified by the postpositional phrase is the first word of the sentence. The rhythms also vary from Western music in terms of how they are organized. 
Korean traditional music is constructed of unequal pulse groupings called Jang-dan, literally translated as "long and short." The aural transmission of the folk song tradition means this traditional music does not rely on mathematical proportions or metrical subdivision as does the Western notion of rhythm, so transcription does not necessarily reflect proper performance practices (Lee, p. 66).

\section{Aural tradition or written?}

With a variety of music traditions comes a variety of teaching traditions. In presenting this collection of pieces, it is important to consider how these songs might have been taught and preserved through generations. All seven of these works have accommodations for the Western ensemble, such as the use of piano accompaniment and metering. Because of this, these pieces all could be taught the same way. Using a consistent teaching system, such as moveable Do solfège, across a variety of musical styles makes students increasingly fluent in that system. That benefit in itself might sufficiently justify the use of a uniform teaching system. However, understanding a music culture also means understanding its historical method of transference. Many folk songs, such as Bright Morning Stars and Arirang in this set, have simple and singable enough melodies that teaching them through rote learning techniques could prove efficient. Many folk songs were created with the understanding that aural learning would be their means of survival. As such, it stands to reason those that did survive across generations would be successfully teachable in that manner. Indeed, the origin of Arirang is uncertain because of its preservation through an aural history rather than a written one. In fact, various versions of the Arirang song exist, belonging to different regions of Korea (Yi, 
1988, p. 35). By incorporating rote learning in such a case as this, the teacher not only works toward efficiently teaching music, but also teaches about the culture and the value of aurally-preserved history in an experiential way. Rote learning would not, however, work as well for some of the other works in this collection, such as Let All the World in Every Corner Sing. Nor would rote learning be as useful for works that have dense homophonic structures, such as Ave Maris Stella.

Among the folk music traditions of America, such as the rural sacred music tradition that produced songs like Bright Morning Stars, styles of music instruction were often deliberately anti-European. The musical style as well as the four-syllable, fourshape method of music teaching was distinct from the European tradition, and the music that grew from it was clearly designed to be learned through that unique system (Stanislaw, 2018, p. 59). Though Bright Morning Stars came from the Appalachian tradition that utilized this shape-note method of singing, the earliest books of printed shape-note hymns do not feature it. The earliest printing of Bright Morning Stars was in Ruth Crawford Seeger's book American Folk Songs for Christmas in 1953 (Seeger, 1953). The song is certainly older than that, being mentioned in the obituary of Elder Elias A. Stamey more than thirty years earlier (Hampton N. S., 1917, p. 19). Even among a music tradition that emphasized memorable melodies and simple harmonies, Bright Morning Stars was a piece that was exclusively transmitted aurally for much of its existence. Such a deliberately simple and melodic work is not as aided by the more labyrinthine European system as a work like Let All the World in Every Corner Sing. Although many of the works in this collection arise from the Western world, several deviate from the tradition of Western art music. Those works, namely Bright 
Morning Stars, This is the Day, and Libertango, might be pragmatically taught by incorporating other methods besides solfège-based sight-reading. In a similar vein, the role of the accompanist in music learning could be more reduced to great effect in the works that are less harmonically sophisticated. It would be difficult for a high school choir to read through Let All the World in Every Corner Sing without the tonal anchoring provided by an accompanist, but it would not be as difficult to read through Bright Morning Stars. Although all the pieces in this collection make use of an accompanist, allowing for some rehearsal time in which the singers perform the more lyrical music in an a cappella setting can help them build musical independence as well as arriving closer to the essence of the music.

\section{Overemphasizing the cultural tradition?}

It is hard to imagine a music teacher being criticized for devoting too much time to teaching the cultural component of the more unfamiliar music they program. After all, misunderstanding the culture could be the most preventative obstacle in the way of students performing foreign music effectively. However, finding a proper time balance is critical. Determining how much a music teacher should talk about a culture and how much of the choir's time should be spent singing is about prioritization. A common rule

of thumb among choral directors is to speak as little as possible in rehearsal. To serve this end, teaching elements of a cultural tradition can often be organically incorporated as part of the music learning process. For instance, many aspects of Gospel performance tradition can correspond with teaching about the history of the Black Church in America. However, several circumstances would necessitate longer conversations than ones 
spanning a few sentences. This is especially true in instances when the music selection involves a culture that actively faces challenging circumstances.

There are many African-American spirituals that utilize a dialect that could be seen as offensive or derogatory. The verbal modifications that resulted in this dialect are based on accommodations made by slaves brought to America that represent a unique resiliency in the face of harsh conditions and a new language that is not fully compatible with the phonetic alphabet of any African tribe. Many leaders in the field consider the use of this dialect to be celebratory and important. This sentiment is echoed in much of the pertinent research literature. Such composers as William Dawson have even, in their own writing, specifically stated that groups performing their works should follow this dialect, as it is essential to the flow of the music and the intended sound of the piece (Dawson). Because it represents the manner in which original spirituals would be sung, modifying the dialect to a more formal English may even be considered "white-washing." However, when a work is performed with a dialect, especially by a predominantly or entirely nonBlack ensemble, it is understandable why an observer might see such performance practice as a sort of vocal blackface. This particular performance consideration is not made simpler by the increasingly complex issue of racial tension in the United States. In cases such as this, it is essential for the music teacher to consider repertoire selections carefully, and then ensure they allow the opportunity for discussion with the students about why they are performing the work in a certain way. Such a discussion could be time-consuming, but this would be an essential component of a conductor giving due diligence to the cultural component of teaching the piece. 
In other instances, conductors should think about how they can teach important elements of a culture efficiently so they do not detract from the time students are actively singing during class. In the case of This is the Day, for instance, one of the elements specific to the Gospel genre this piece derives from is improvisation. In general, improvisation is a skill that is not effectively taught through a wordy explanation. Rather, students should be encouraged to listen to good vocal models and experiment with the improvising on their own. Parts of This is the Day that are largely led by a soloist or a small group might provide an opportunity for the conductor to step away from the podium and allow the ensemble to be led from within. Teaching improvisation, it would seem, involves more subtle guiding than authoritarian and verbose instruction. In this case, as in the case with many of these music traditions, the most meaningful gift the teacher can bestow on the students is the empowerment to learn and engage more with these traditions on their own. This goal could be accomplished through various pragmatic means, such as allowing students to research and write their own program notes. Overall, the most beneficial tool at the teacher's disposal in efficiently teaching about a new music culture is demonstrating an infectious enthusiasm and respect for all that the culture has to offer by engaging with its traditions. 


\section{CHAPTER 5: CONCLUSION}

\section{Summary}

The works of the 2020 SATB Tennessee All-State repertoire present a wellbalanced selection of pieces incorporating music from a variety of cultural traditions. Providing students with a music education that is culturally responsive necessitates selection of repertoire that is, as here, representative of a variety of music cultures. In addition to the consideration of musical pedagogical goals, music educators must also consider cultural pedagogical goals that are achievable and work to broaden the worldview of their students, encouraging them to be engaged, receptive, and responsible citizens of a global community. Providing such a cross-cultural education inevitably involves unique challenges and risks, the most prominent of which might be poorly representing an important musical tradition of a culture outside a music teacher's heritage. With this in mind, this research has led to three principal recommendations that should be considered by any teacher seeking to incorporate music from cultures previously unfamiliar to them.

First, the programming of a piece presupposes a thorough research process. The research should be done early in order to ensure that a teacher will feel comfortable in her role as principal conduit for a given music tradition. Should a teacher study a music culture and feel insufficiently prepared to discuss and understand its nuances, he does the students no favors by going ahead with the plan to teach them a piece from that tradition. 
It is important to consider what music one could be comfortable teaching. Conversely, if a piece is intended to stretch the choir's cultural knowledge, it is important to select works that do so. One must avoid being overly cautious and as a result miss out on rich traditions of music. Upon completing thorough research, one can program and present works that reflect a variety of carefully considered music traditions with which the teacher has at least a reasonable degree of comfort in teaching.

Second, it is essential to involve multiple voices in the process of teaching works from other cultures. Cultural history is a living human history, and thus humans with the relevant background should be involved at every step. These culture bearer voices could arise from within the group, from the school, or from the larger community. However, these voices should be present and they should reflect as many unique perspectives as is feasible. Involving such voices is how the students may be empowered to engage in the continued dialogue about multicultural celebration and solidarity that must accompany the teaching in a culturally responsive format.

Finally, the teacher must be willing to embrace a certain degree of what Hook called "cultural humility" (2013, p. 353). Even after thorough research and doing one's best to honor a music tradition, cultural biases are, at some level, inevitable. Being open to listening to the voices of a culture and acknowledging one's own shortcomings in attempting to understand that culture's lived experience requires humility. Even conductors hailing from a diverse background should acknowledge that their lived experience is not identical to that of every potential culture bearer. In the end, presenting a work of art drawn from another cultural tradition involves listening to its authentic voices, doing the best one can to present a version that remains culturally valid, and 
allowing for the possibility that one's version might be flawed in the eyes of some. A music teacher is but one voice attempting to communicate a world of rich musical traditions. It is impossible for one teacher to perfectly represent the experience of millions. However, with disciplined research, the proper guiding voices, and a certain degree of humility, a music teacher can unlock these music cultures for countless students, inspiring them to engage with diverse cultural traditions both in music and in life.

\section{Recommendations for future research}

The sociopolitical landscape continues to evolve on issues of culture, especially in terms of how to usefully and thoughtfully incorporate the growing diversification of the United States. Culturally responsive education is a phrase that educators are becoming more and more familiar with as more presentations and publications deal with its difficulties and benefits. The challenges of addressing inclusivity and diversity in society will not be resolved by a single publication, and these challenges will likely be a wellspring for consequential research in years to come. This conversation is an everevolving one, and as such any new contribution to it must be done with an understanding of contemporary societal developments, which are doubtless incongruent from those at the time of this writing. That being said, there are a few timeless considerations any author seeking to contribute to this conversation might bear in mind.

The first recommendation is to accept a certain humility in approaching the sacred traditions of other cultures. The research of world music pedagogy involves seeking the knowledge and opinions of individuals from a dissimilar cultural background, regardless 
of any single author's ethnic identity. Being aware of one's own inherent culturally-based biases will contribute to the greater appreciation and understanding of those cultural traditions that are unfamiliar.

In whatever work continues to be performed in this field, it would be prudent to consider more data-driven approaches to resolving questions. The great majority of literature found during the research process for this document was qualitative in nature. For a field as subjective and ineffable in its effects on students as music, this predisposition toward qualitatively-driven research approaches is reasonable. However, to achieve generalizable findings regarding the appropriateness of teaching strategies for a topic as volatile as cultural exchange, it would be useful to receive feedback from as large a sample as possible by presenting questions whose answers have discrete measurement criteria. The most essential action item for music educators teaching about music from other cultures is to involve multiple individuals from those cultures in the process whenever possible. Collecting data representative of a large group of people would ensure a larger diversity of perceptions surrounding this complex issue. 


\section{REFERENCES}

2014 Music Standards. (2014, June 4). Retrieved from National Association for Music Education: https://nafme.org/my-classroom/standards/

Abril, C. R. (2006). Music that represents culture: Choosing music with integrity. Music Educators Journal, 1(93), 38-45.

ACDA Constitution and Bylaws. (2021, April). Choral Journal, 82.

Ballantine, C. J. (1984). Music and its social meanings. New York: Gordon and Breach.

Bartolome, S. J. (2019). World music pedagogy, volume V: Choral music education. New York: Routledge.

Bowers, J. P. (2021, March 19). Culturally Responsive Pedagogy in the Choral Classroom. 2021 American Choral Directors Association National Convention.

Boyd, B. (2020, November, December). Sounds of Blackness: A Focus Issue on Racial Harmony; Just in Case You've Forgotten: A Focus Issue On Black Composition and Arranging. Choral Journal, 1.

Bumgarner, A. (2021, March). 2021 National Conference Program Book. Choral Journal, 1.

Campbell, P. S. (2002, September). Music Education in a Time of Cultural Transformation. Music Educators Journal, 89, 27-32.

Cho, R. (2015, May). Cultural Appropriation and Choral Music: A Conversation That Can Make Both Our Music and Community Better. Choral Journal, 59-63.

Dawson, W. L. (n.d.). Rehearsal Suggestions for Ezekiel Saw de Wheel. Dawson Collection at MARBL, Emory University.

de Brey, C., Musu, L., \& McFarland, J. (2019). Status and Trends in the Education of Racial and Ethnic Groups 2018. Washington, DC: National Center for Education Statistics.

Dodds, J. P. (1983, May). Music as a multicultural education. Music Educators Journal, 69(9), 33-34.

Dungee, J. A. (2020, November). A Pedagogy for Living: Applying Restorative, AntiRacist Pedagogy in the Choral Classroom. Choral Journal, 10-14. 
Ešenvalds, Ē. (2021, March 19). Ēriks Ešenvalds \& Ethan Sperry In Conversation. (E. Sperry, Interviewer) Edition Peters.

Forrest, D. (2012). Arise, my soul, arise. Columbus, OH: Beckenhorst Press, Inc.

Frey, W. H. (2020, July 1). The nation is diversifying even faster than predicted, according to new census data. Retrieved from Brookings: https://www.brookings.edu/research/new-census-data-shows-the-nation-isdiversifying-even-faster-than-predicted/

Froehlich, H. C. (2007). Sociology for music teachers: Perspectives for practice. Upper Saddle River, NJ: Pearson Prentice Hall.

Glass, J. E. (2021, February). Music matters: A pedagogical framework for literature selection. Choral Journal, 22-32.

Goble, J. S. (2010). What's so important about music education? New York: Routledge.

Hampton, K. (2019). This is the Day. Corvallis, OR: earthsongs.

Hampton, N. S. (1917). 6th Annual Session. Minutes of the Avery County Baptist Association (p. 19). Brookside, NC: McGuire.

Hodges, D. A., \& Sebald, D. C. (2011). Music in the human experience: An introduction to music psychology. New York: Routledge.

Hoffer, C. R. (2008). Introduction to Music Education (3rd ed.). Long Grove, IL: Waveland Press, Inc.

Hook, J. N., Davis, D. E., Owen, J., Worthington, E. L., \& Utsey, S. O. (2013). Cultural humility: Measuring openness to culturally diverse clients. Journal of Counseling, 3(60), 353-366. doi:https://doi.org/10.1037/a0032595

J.W. Pepper. (2021). State and Festival Lists. Retrieved from https://www.jwpepper.com/sheet-music/services-state-festival.jsp

Jordan, J. (2017). Inside the choral rehearsal. Chicago: GIA Publications, Inc.

Kirchner, S. (2005). Bright morning stars. Santa Barbara, CA: Santa Barbara Music Publishing, Inc.

Korea National Gugak Center. (n.d.). Traditional Korean Key and Mode. Retrieved March 28, 2021, from https://www.gugak.go.kr/site/main/index001?menuid=001\&lang=en

Lee, D. (2020, November). A Study of "Jeongseon Arirang" by Min-Hyeong Lee: Elements of Korean Traditional Folk Music. Choral Journal, 63-69. 
Music Educators National Conference GO Project - Committee 18. (1969, February). Final report - 1969. University of Maryland, MENC Historical Center Music Library.

Piazzolla, A. (2000). Libertango. (O. Escalada, Ed.) San Diego, CA: Neil A. Kjos Music Company.

Quadros, A. (2019). Focus: Choral music in global perspective. New York: Routledge.

Reimer, B. (2003). A philosophy of music education: Advancing the vision. Upper Saddle River, NJ: Prentice Hall.

Seeger, R. C. (1953). American Folk Songs for Christmas. Garden City: Doubleday \& Company, Inc.

Shangkuan, P. (2021, February 22). Personal communication. (M. Colavita, Interviewer)

Sperry, E., \& Goetze, M. (2014). Vocal versatility in bel canto style. Choral Journal, $2(55)$.

Stanislaw, R. (2018, November). Rural Sacred Choral Music of Post-Colonial America. Choral Journal, 59-61.

Thomas, M. (2010). Ave maris stella. Corvallis, OR: earthsongs.

Titon, J. T. (2018). Worlds of music: An introduction to the music of the world's peoples, shorter version. Boston, MA: Cengage Learning.

Volk, T. M. (1998). Music, education, and multiculturalism. New York: Oxford University Press.

Westminstertownhall. (2019, November 13). André Thomas- The Meaning and Impact of African American Spirituals - 11/12/19 . Retrieved from YouTube: https://www.youtube.com/watch?v=xnwJ2I1IlJs

Williams, R. V. (2010). Let all the world in every corner sing. (C. Courtney, Ed.) Columbus, OH: Beckenhorst Press, Inc.

Woo, H. W. (2018). Arirang. Chicago: Walton.

Yi, P. (1988, July). Musical Study on Arirang. Korea Journal, 28(7), 35. 


\section{CURRICULUM VITA}

NAME:

ADDRESS:

DOB:

EDUCATION

\& TRAINING:
Michael Ian Colavita

School of Music

University of Louisville

Louisville, KY 40292

Livingston, New Jersey - January 26, 1996

Master of Music Education (anticipated)

University of Louisville, Louisville, KY

2018-2021

Master of Music in Performance (Choral Conducting emphasis) University of Louisville, Louisville, KY

2018-2020

Bachelor of Arts (Music), Bachelor of Science (Neuroscience)

Washington and Lee University, Lexington, VA

2014-2018

TEACHING

EXPERIENCE:

Director of Choral Activities

Montgomery Bell Academy, Nashville, TN

2020-present

Graduate Teaching Assistant, Director of Singing Cardsmen University of Louisville, Louisville, KY

2019-2020

PROFESSIONAL

ASSOCIATIONS: Tennessee Music Educators Association (2020-present)

Mid-Tennessee Vocal Association (2020-present)

American Choral Directors Association (2017-present)

National Association for Music Education (2015-present) 